\title{
An Engineering and Cost Analysis of a Dry Cooling System Augmented with a Thermal Storage Pond
}

\author{
M. K. Drost \\ R. T. Allemann
}

September 1978

Prepared for the U.S. Department of Energy under Contract EY-76-C-06-1830

Pacific Northwest Laboratory Operated for the U.S. Department of Energy by Battelle Memorial Institute 


\title{
NOTICE
}

This report was prepared as an account of work sponsored by the United States Government. Neither the United States nor the Department of Energy, nor any of their employees, nor any of their contractors, subcontractors, or their employees, makes any warranty, express or implied, or assumes any legal liability or responsibility for the accuracy, completeness or usefulness of any information, apparatus, product or process disclosed, or represents that its use would not infringe privately owned rights.

The views, opinions and conclusions contained in this report are those of the contractor and do not necessarily represent those of the United States Government or the United States Department of Energy.

\author{
PACIFIC NORTHWEST LABORATORY \\ operated by \\ BATTELLE \\ for the
}

UNITED STATES DEPARTMENT OF ENERGY

Under Contract EY-76-C-06-1830

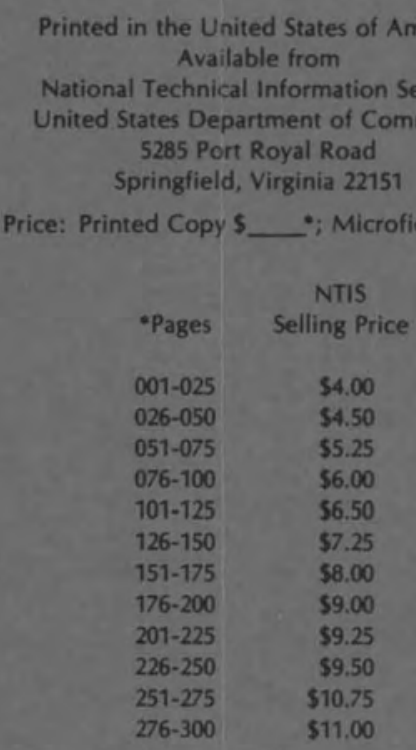


PNL -2745

33679000491821

UC-12

AN ENGINEERING AND COST ANALYSIS OF A DRY COOLING SYSTEM AUGMENTED WITH A THERMAL STORAGE POND

M. K. Drost

R. T. Allemann

September 1978

Prepared for the U.S. Department of Energy under Contract EY-76-C-06-1830

Pacific Northwest Laboratory Richland, Washington 99352 


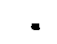




\section{FOREWORD}

The Dry Cooling Enhancement Program at Pacific Northwest Laboratory (PNL) was initiated with a program scope that included the following near-term and ultimate emphases.

Near-Term Objectives:

- Develop economic and performance models for cost optimization of total heat rejection systems using dry and dry/wet cooling.

- Analyze and disseminate operating experience on existing dry-cooled plant performance.

- Demonstrate certain features of existing technology equipment to provide confidence for specification by utilities.

Ultimate Objective:

- Promote water conservation through industry use of dry cooling by developing and demonstrating the reliability of lower cost systems. The development of advanced dry/wet systems is also considered to be within this scope.

The following documents have been issued, reporting the results of the work toward these objectives.

Cost optimization of dry-cooled heat rejection systems:

A REVIEW AND ASSESSMENT OF ENGINEERING ECONOMIC STUDIES OF DRY-COOLED ELECTRICAL GENERATING PLANTS. B. C. Fryer, BNWL-1976, March 1976.

HEAT TRANSFER AND PRESSURE DROP CHARACTERISTICS OF DRY TOWER EXTENDED SURFACES. PART I: HEAT TRANSFER AND PRESSURE DROP DATA. PFR Engineering Systems, Inc., PFR 7-100, March 1976.

HEAT TRANSFER AND PRESSURE DROP CHARACTERISTICS OF DRY TOWER EXTENDED SURFACES. PART II : DATA ANALYSIS AND CORRELATION. PFR Engineer ing Systems, Inc., PFR 7-102, June 1976. 
Analysis of performance of existing dry-cooled plants:

DRY COOLING TOWER PROGRAM: RESULTS OF INDUSTRIAL CONTACTS THROUGH AUGUST 1974. BNWL-1878, November 1, 1974.

A SURVEY OF MATERIALS AND CORROSION PERFORMANCE IN DRY COOLING APPLICATIONS. A. B. Johnson, Jr., D. R. Pratt and G. E. Zima, BNWL-1958, March 1976.

EUROPEAN DRY COOLING TOWER OPERATING EXPERIENCE. J. G. DeSteese and K. Simhan, BNWL-1955, March 1976. MATHEMATICAL AND EXPER IMENTAL INVESTIGATIONS ON DISPERSION AND RECIRCULATION OF PLUMES FROM DRY COOLING TOWERS AT WYODAK POWER PLANT IN WYOMING. Y. Onishi and D. S. Trent, BNWL-1982, February 1976.

ALUMINUM ALLOY PERFORMANCE UNDER DRY COOLING TOWER CONDITIONS. A. B. Johnson, Jr., S. Begaj, M. W. Martini, and R. P. May, PNL-2392, December 1977.

Advanced dry (dry/wet)-cooled systems:

PRELIMINARY EVALUATION OF WET/DRY COOLING CONCEPTS FOR POWER PLANTS. W. B. Loscutoff, BNWL-1969.

COMPATABILITY OF AMMONIA WITH CANDIDATE DRY COOLING SYSTEM MATERIALS. D. R. Pratt, BNWL-1992, Apri1 1976.

SCALE FORMATION IN DELUGED DRY COOLING SYSTEMS. D. R. Pratt, BNWL-2060, March 1976.

AMMONIA AS AN INTERMEDIATE HEAT EXCHANGE FLUID FOR DRYCOOLED TOWERS. R. T. ATTemann, B. M. Johnson, and G. C. Smith, BNWL-SA-5997, September 1976.

A group of reports (including this report) has been issued that serves the dual purpose of: 1) developing cost optimization models for dry cooling systems based on available technology and 2) comparing the results of analyzing the costs of these systems with the projected cost of several advanced dry and dry/wet systems. Included in this group are:

AN ENGINEERING AND COST COMPARISON OF THREE DIFFERENT ALL-DRY COOLING SYSTEMS. B. C. Fryer, D. W. Faletti, Daniel J. Braun, David J. Braun and L. E. Wiles, BNWL-2121, September 1976. 
A STUDY OF THE COMPARATIVE COSTS OF FIVE WET/DRY COOLING TOWER CONCEPTS. F. R. Zaloudek, R. T. Allemann, D. W. Faletti, B. M. Johnson, H. L. Parry, G. C. Smith, R. D. Tokarz, and R. A. Walter BNWL-2122, September 1976.

DRY COOLING OF POWER GENERATING STATIONS: A SUMMARY OF THE ECONOMIC EVALUATION OF SEVERAL ADVANCED CONCEPTS VIA A DESIGN OPTIMIZATION STUDY AND A CONCEPTUAL DESIGN AND COST ESTIMATE. B. M. Johnson, R. T. Allemann, D. W. Faletti, B. C. Dryer and F. R. Zaloudek, BNWL-2120, September 1976.

COSTS AND COST ALGORITHMS FOR DRY COOLING TOWER SYSTEMS. P. A. Ard, C. H. Henager, D. R. Pratt and L. E. WiTes, BNWL-2123, September 1976.

A USER'S MANUAL FOR THE BNW-I OPTIMIZATION CODE FOR DRY-COOLED POWER PLANTS. David J. Braun, Daniel J. Braun, Warren V. DeMier, D.W. Falett $j$ and L. E. Wiles, BNWL-2180, January 1977.

COMPARATIVE COST STUDY OF FOUR WET/DRY COOLING CONCEPTS THAT USE AMMONIA AS THE INTERMEDIATE HEAT EXCHANGE FLUID. R. D. Tokarz, Daniel J. Braun, B. M. Johnson, R. T. ATlemann, David J. Braun H. L. Parry, G. C. Smith and F. R. Zaloudek, PNL-2661, September 1978.

AN ENGINEERING AND COST ANALYSIS OF A DRY COOLING SYSTEM AUGMENTED WITH A THERMAL STORAGE POND. M. K. Drost and R. T. Allemann, PNL-2745, September 1978.

Two reports have been issued which consider the future need for any cooling and the potential benefit/cost ratio of a large-scale demonstration.

AN OVERVIEW OF ECONOMIC, LEGAL, AND WATER AVAILABILITY FACTORS AFFECTING THE DEMAND FOR DRY AND WET/DRY COOLING OF THERMAL POWER PLANTS. P. L. Hendrickson, BNWL-2268, June 1977.

ESTIMATION OF BENEFITS FROM DEMONSTRATING ADVANCED DRY COOLING TECHNOLOGY: A FRAMEWORK AND PARTIAL ANALYSIS. J. W. Currie and T. J. Foley, BNWL-2182, Apri1 1977. 



\section{ACKNOWLEDGEMENTS}

This report contains an account of the work sponsored by the Division of Advanced Systems and Materials Production of the U.S. Department of Energy (DOE) under the Dry Cooling Enhancement Program at PNL. This work was completed under the direction of I. Helms, Project Officer; W. F. Savage, Manager, DOE Division of Advanced Systems and Materials Production; and B. M. Johnson, Manager of the Dry Cooling Enhancement Program at PNL.

This report was edited by $A$. J. Currie. Word processing was done by R. A. Keefe and P. Goodenough. 
.

- 


\section{SUMMARY}

The widespread application of dry cooling for waste heat rejection in thermal power plants could have a major impact on conserving the water resources of the U.S. Many studies have shown that the dry cooling systems currently available are not as economical for most power plants as evaporative cooling systems.

One problem confronting the dry cooled power plants is the mismatched sizing for many systems because the maximum demand for power (occurring at maximum ambient temperature) and maximum cooling capacity (occurring at minimum ambient temperature) are not concurrent. The thermal storage pond concept can reduce this mismatch. The concept allows water to be cooled during the night, and stored until needed during the peak demand period, which would occur in the afternoon. The dry cooling system would consist of an induced mechanical-draft dry tower and a thermal storage pond. The water returning from the tower would either go directly to the plant or be diverted to the thermal storage pond. The pond would be lined, covered, and equipped with necessary pumps and piping to provide cooling water to the plant when the pond is in service.

This report describes an engineering and cost study of the capacitive thermal storage pond added to a state-of-the-art dry cooling system. The purpose of the study was to assess the potential for reducing the cost of all-dry cooling for thermal electric power plants using a dry cooling system that includes a thermal storage pond.

The thermal storage pond concept was chosen for study because earlier research $(1)$ had shown that the approach could substantially reduce the incremental cost of dry cooling. However, little effort has been made to include the concept into the site design of any dry-cooled plant or even into any large-scale design study. The objective of the work reported here was to determine whether thermal storage ponds should be included into the plans for future dry-cooled plants. 
In this study the concept was investigated by modifying the existing BNW-I computer code, $(2,3)$ used for optimizing dry cooling tower designs. The modified code was used to optimize a thermal storage pond dry cooling system.

Using the modified BNW-I computer code, the effect of varying significant design parameters was investigated. The parametric study included studying the effects of varying turbine type, pond size, replacement energy costing, capacity penalty methodology, pond location with respect to the dry cooling tower, design temperature and site location (meteorology).

Incremental power production costs for dry cooling (i.e. the portion of the cost of bus-bar electricity from the plant which is attributable to the cost of building and operating the heat rejection system) with a thermal storage pond system were determined for meteorologies of both Wyodak, Wyoming and Phoenix, Arizona. For Wyodak the incremental cost of dry cooling with a thermal storage pond was $2.81 \mathrm{mill} / \mathrm{s} / \mathrm{kWh}$ as compared to $2.55 \mathrm{mills} / \mathrm{kWh}$ for a system without a thermal storage pond. For Phoenix the incremental cost of dry cooling with a thermal storage pond was $3.66 \mathrm{mills} / \mathrm{kWh}$ as compared to 4.31 mills/kWh for a system without a thermal storage pond.

The results indicate that the thermal storage pond concept will not decrease the incremental cost of dry cooling for a site with meteorology similar to Wyodak, Wyoming. The thermal storage pond concept does result in an estimated $15 \%$ reduction in incremental cost for a site with meteorology similar to Phoenix, assuming the plants are equipped with modified conventional turbines. If both plants are equipped with high back pressure turbines, then the thermal storage pond concept has no cost advantage.

The parametric study indicates that the high back pressure turbine results in the lowest cost cooling system for all cases considered. This would change if the high back pressure turbine were substantially more expensive than the other turbine types.

The results appear to be insensitive to several different methodologies of calculating replacement energy. However, the results appear to be quite sensitive to the method of evaluating capacity penalty and to site 
meteorology. In general, the thermal storage pond concept trades off the capacity penalty versus the capital cost of the pond. Because both meteorology and the method of evaluating capacity penalty affect the capacity penalty, it is reasonable that they should have the greatest effect on the results. The sensitivity of the results to the method of evaluating capacity penalty is disturbing because there is no single accepted method of evaluating capacity penalty. The results are also quite sensitive to the assumed pond layout. The assumed pond layout can result in a $5 \%$ reduction in incremental cooling costs for the lowest cost layout, as compared to the base case layout where the pond is located 600 feet from the dry cooling tower.

If the use of a modified conventional turbine with the dry-cooled system is stipulated in order to stay with proven technology for large turbines, then results of this study show that in extremely hot climates the thermal storage pond can reduce the cost of dry cooling. This is particularly true if site conditions allow locating the pond close to the cooling tower. In more moderate climates it appears that the thermal storage pond concept does not reduce the cost of dry cooling. If no cost penalty is assigned to high back pressure turbines and it can be used, then the thermal storage pond has no advantage in hot climates. However, collateral use of the pond for makeup or emergency cooling water storage may decrease the cost. 
CONTENTS

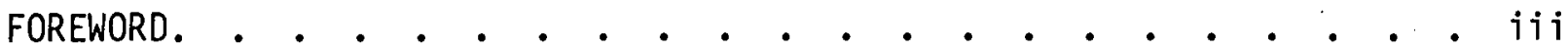
ACKNOWLEDGEMENTS . . • . . . . . . . . . . . . . . . . vii

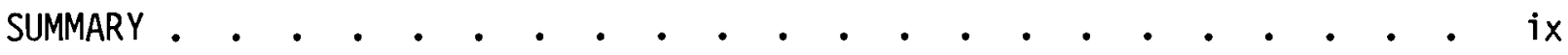

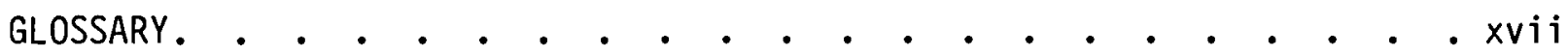
1.0 INTRODUCTION. • . . . . . . . . . . . . . . . . . 1

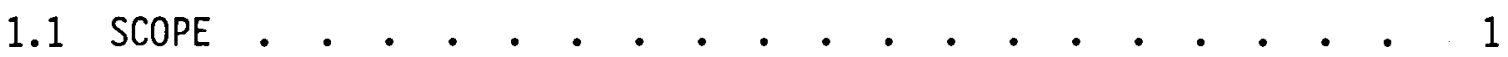

1.2 BACKGROUND. . . . . . . . . . . . . . . . . . 2

1.3 DOE/PNL DRY COOLING ENHANCEMENT PROGRAM . . • • • . . . . 4

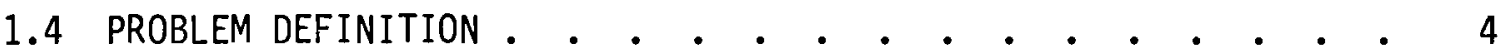

2.0 DESIGN BASE FOR DRY-COOLED PLANT WITH

THERMAL STORAGE POND . . . . . . . . . . . . . . . . 7

2.1 GENERAL DESCRIPTION AND SITE ARRANGEMENT. • . • • • • . 7

2.2 THERMAL STORAGE POND • • • • • • . • • • • • • • 12

2.2.1 Hydrothermal Characteristics . . . . . . . . . 12

2.2.2 Inlet Structure and Barriers . . . . . . . . . 13

2.2.3 Cover and Lining . . . . . . . . . . . . . 13

2.3 PIPING SYSTEM. . . . . . . . . . . . . . . . . 14

2.3.1 Pond Supply Piping. . . . . . . . . . . . . 14

2.3.2 Pond Return Piping. . . . . . . . . . . . . 15

2.3.3 Pond Pumping Plant. . . . . . . . . . . . 15

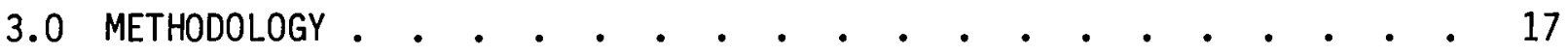

3.1 COMPUTER PROGRAM. • • • • • • • . • • • • • • . 17

3.2 POND DESIGN MODEL . • . . • . • . . . • . . . . 18

3.3 ANNUAL COST AND PERFORMANCE MODEL • . . . . . . . . . 20

3.3.1 "Pond Out of Service" Mode1 • • • . • . • . . 21

3.3.2 "Pond In Service" Mode1 . . . . . . . . . . 22

3.3.2.1 Plant Performance Model . . . . . . 23

3.3.2.2 Plant Performance Algorithm. . . . . . 26

3.3.2.3 Incremental Cost Model . . . . . . . 27

3.3.2.4 Incremental Cost Algorithm . . . . . . . 28

3.3.3 Discussion of Model . . . . . . . . . . . . 29 


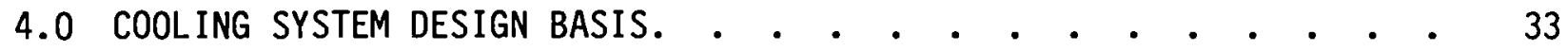

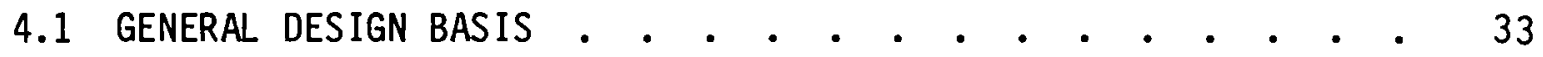

4.2 ADDITIONAL DESIGN BASIS LIMITATIONS . . . . . . . . . 33

5.0 RESULTS . . . . . . . . . . . . . . . . . . . . . 37

5.1 GENERAL CONSIDERATIONS. . . . . . . . . . . . . . 37

5.2 TURBINE TYPE . . . . . . . . . . . . . . . . . 42

5.2.1 Conventional Turbine. . . . . . . . . . . . 43

5.2.2 Modified Conventional Turbine . . . . . . . . . 43

5.2.3 High Back Pressure Turbine . . . . . . . . . . 43

5.3 TURBINE OPTIMIZATION ANALYSIS . • . . . . . . . . . . 43

5.4 POND STORAGE . . . . . . . . . . . . . . . . . . 44

5.5 ENERGY COST . . . . . . . . . . . . . . . . . 48

5.6 POND CAPITAL COST . . . . . . . . . . . . . . . . . . 49

5.7 CAPACITY PENALTY COST . . . . . . . . . . . . . . . . 52

5.8 DESIGN TEMPERATURE . . . . . . . . . . . . . . . . . 57

5.9 METEOROLOGY . . . . . . . . . . . . . . . . . 58

6.0 CONCLUSIONS . . . . . . . . . . . . . . . . . . . . . . . . . 67

REFERENCES . • . . . . . . . . . . . . . • • . . . . 69 
1 Thermal Storage Pond Concept . . . . . . . . . . . . 9

2 Conceptual Arrangement . . . . . . . . . . . . . . 10

3 Pond Cross Section. . . . . . . . . . . . . . . . 13

4 Inlet Structure. . . . . . . . . . . . . . . . . . 14

5 Conceptual Piping Layout. . . . . . . . . . . . . . 16

6 Cumulative Temperature Profiles . . . . . . . . . . . 24

7 Plant Heat Balance. . . . . . . . . . . . . . . 25

8 Plant Generation Profile with Pond Fixed Daily Cycle . . . . 30

9 Plant Generation Profile with Ideal "Bleed-in" Cycle . . . . . 31

10 Plant Generation Profile with Failure to Predict Ambient Temperature . . . . . . . . . . . . . . 31

11 Comparison of Incremental Power Production Costs. . . . . . . 38

12 Parametric Study Incremental Power Cost, mills/kWh (Design Temperature of $30 \mathrm{~F}$ ) . . . . . . . . . . . . . 39

13 Parametric Study Incremental Power Cost, mills/kWh (Design Temperature of 50 F) . . . . . . . . . . . . 40

14 Parametric Study Incremental Power Cost, mills/kWh (Design Temperature of $70 \mathrm{~F}$ ) . . . . . . . . . . 41

15 Conceptual Close-in Pond Arrangement. . . . . . . . . . 51

16 Generation Profile and Capacity Penalty. . . . . . . . . 54

17 System Excess Capacity . . . . . . . . . . . . . . 55

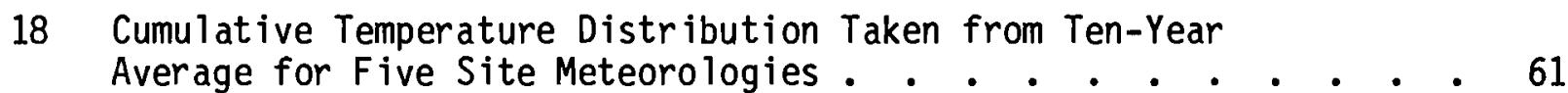




\section{$\underline{\text { TABLES }}$}

1 Design Basis. . . . . . . . . . . . . . . . . . 34

2 Cost Summary by Turbine Type for Dry-Cooled Plant Without Thermal Storage Pond for Wyodak . . . . . . . . . 45

3 Cost Summary by Turbine Type for Dry-Cooled Plant With Thermal Storage Pond for Wyodak . . . . . . . . . . 46

4 Dry Cooling System Optimization for Three Pond Storage Capacities for Wyodak. . . . . . . . . . . . 47

5 Dry Cooling System Optimization for Alternate Energy Penalty Methodology for Wyodak . . . . . . . . . . . . 50

6 Dry Cooling System Optimization for Alternate Pond Location for Wyodak . . . . . . . . . . . . . . 53

7 Dry Cooling System Optimization for Alternate Capacity Penalty Methodology for Wyodak . . . . . . . . . 56

8 Dry Cooling System Optimization for a Design Temperature of $30^{\circ} \mathrm{F}$ for Wyodak . . . . . . . . . . . . 59

9 Dry Cooling System Optimization for a Design Temperature of $70 \mathrm{~F}$ for Wyodak . . . . . . . . . . . 60

10 Dry Cooling System Optimization for Phoenix Meteorology . . . . 63

11 Dry Cooling System Optimization for Phoenix Meteorology and Close-in Pond Location . . . . . . . . . . . . . 64

12 Dry Cooling System Optimization for Phoenix Meteorology and No Thermal Storage Pond with Various Turbine Designs . . . . 65

13 Dry Cooling System Optimization for Phoenix Meteorology and Thermal Storage Pond with Various Turbine Designs . . . . . 66 


\section{GLOSSARY}

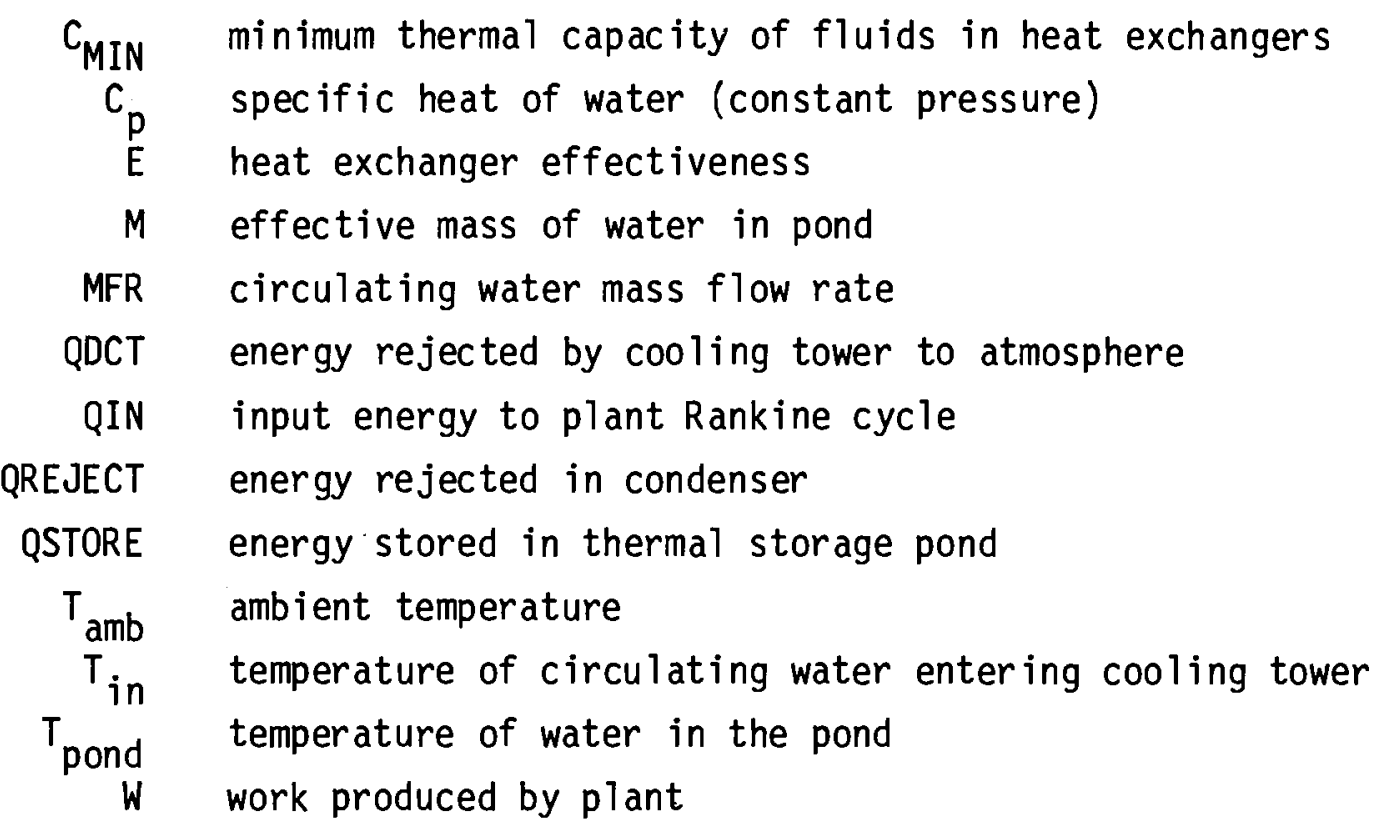

\section{Subscripts}

$\mathrm{H}$ value during heatup mode

$L \quad$ value during cooldown mode 

AN ENGINEERING AND COST ANALYSIS OF A DRY COOLING

SYSTEM AUGMENTED WITH A THERMAL STORAGE POND

\subsection{INTRODUCTION}

The study described in this report was performed as part of the U.S. Department of Energy's Dry Cooling Enhancement Program at the Pacific Northwest Laboratory (PNL). The objective of the study was to determine the potential for reducing the high cost associated with all-dry cooling of steam electric power plants by using capacitive thermal storage ponds.

\subsection{SCOPE}

This report documents the engineering and cost analysis of an all-dry cooling system operating in conjunction with a thermal storage pond. The all-dry cooling system is assumed to be a state-of-the-art system using metal finned tubes. The thermal storage pond is included to provide energy storage that allows more efficient plant operation throughout the daily ambient temperature cycle.

Two types of thermal storage ponds have been proposed, a covered pond and an uncovered pond. The uncovered pond has the added effect of heat rejection (by evaporation) from the surface and heat absorbtion (by radiation and conduction) to the surface. In this study only covered ponds were considered because an uncovered pond is no longer an all dry system but must now be considered a dry/wet system. The storage pond will undergo an additional diurnal change in heat content because of interaction with the surroundings (i.e., sun and atmosphere) and will function in a manner similar to a conventional cooling pond in series to a dry tower. Thus the cost effectiveness of an uncovered pond must be compared with a logical alternative approach to dry/wet cooling, e.g., an evaporative cooling tower in conjunction with dry cooling. A further parallel may be drawn with the comparative 
cost-effectiveness of cooling ponds and evaporative towers in conventional cooling (evaporative) systems. Since the relative advantage of cooling towers vis-a-vis cooling ponds is very site dependent, the decision was made to exclude the consideration of uncovered thermal storage ponds from this study. This decision seems further justified by the studies in Reference 1 which indicate that uncovered ponds do not substantially increase the effectiveness of the thermal storage pond performance, despite the consumption (evaporation) of water.

To allow a meaningful comparison with other proposed all-dry cooling systems, this study used the same assumptions and design base as those documented in Reference 1. These are described in Section 2. The methodology and its justification are presented in Section 3; the cooling system design base is described in Section 4. Section 5 discusses the results of parametric studies of the combined all-dry cooling system operating in conjunction with a thermal storage pond. The conclusions appear in Section 6 .

\subsection{BACKGROUND}

The increased competition for existing water supplies has led to an increased interest in the use of dry cooling towers for steam power plant cooling. This is particularly important in the arid West and Southwest where water is sufficiently scarce that power plants with dry cooling towers have been built.

The primary problem associated with the use of dry cooling towers for power plants is the severe economic penalties associated with the unavoidably higher heat rejection temperature in warm weather than with an equivalent wet cooling tower. These higher heat rejection temperatures not only increase the $\mathrm{plant}$ heat rate, making power more costly, but also may require reducing plant output on hot summer days when U.S. power demands are likely to be highest. This loss of capacity would have to be compensated for by the availability of excess capacities in the plant or in the utility's system, or through the purchase of power. 
Because of these economic penalties associated with dry cooling towers there are strong incentives to develop systems that reduce the cost of using dry cooling towers. Several methods are currently being investigated at PNL. These include advanced dry cooling systems and wet augmentation of dry systems. In this study an alternate method of improving dry cooling tower performance is considered, that of adding a capacitive thermal storage pond to the dry cooling system.

One problem inherent with an all-dry cooling system is that the maximum demand for heat rejection may occur during the hottest period of the day when a dry cooling tower's heat rejection capacity is the lowest. Conversely, the dry cooling tower has its greatest heat rejection capacity during the cool nights when the heat rejection capacity is probably not required. The thermal storage pond has been proposed as a method of utilizing the peak in cooling capacity during the peak in heat rejection demand. During the cool evening the thermal storage pond would be filled with relatively cool water from the cooling tower. This water would be used during the hot part of the following day to allow more efficient heat rejection from the steam plant during the period of peak heat rejection.

It has been suggested in Reference 1 that a thermal storage pond will reduce the cost of dry cooling by increasing the plant capacity during hot weather, therefore reducing the cost of replacement capacity and power. To meaningfully evaluate this suggestion, the incremental cost of an optimized dry cooling system with a thermal storage pond must be compared to the incremental cost of an optimized dry cooling system without a thermal storage pond. In this study the incremental cost of a dry cooling system with a thermal storage pond was determined using the same assumptions and costs as used in Reference 2. This facilitated comparing the cost associated with the thermal storage pond with other all-dry cooling concepts already designed and costed in Reference 2. 


\subsection{DOE/PNL DRY COOLING ENHANCEMENT PROGRAM}

The objective of the U.S. Department of Energy/Pacific Northwest Laboratory (DOE/PNL) Dry Cooling Enhancement Program is to develop, demonstrate and disseminate to potential users dry and wet/dry cooling tower technology, which can be applied to conserve scarce water resources, increase power plant siting flexibility and result in a minimum degradation of power plant operation during yearly operation.

As planned, the Dry Cooling Enhancement (DCE) Program was divided into six separate tasks:

- Task 1 Program planning and management

- Task 2 Role of dry cooling in meeting national energy needs

- Task 3 Cooperative testing and evaluation of dry cooling

- Task 4 Analysis and design assessment of new dry cooling ideas

- Task 5 Development of unique design features

- Task 6 Planning and commercialization.

This report presents work performed under Task 4. The objective of this task is to provide critical appraisals of new technology or design concepts. Continuing appraisals, similar to the one reported here, will be performed through analytic evaluation, design studies and economic evaluation to normalize and compare claims of costs and performance of competing concepts. The results of this task will be used to identify the most advantageous concepts for further development and demonstration under Task 6 of this program.

\subsection{PROBLEM DEFINITION}

The methods associated with optimizing and costing a dry cooling system have been discussed in Reference 2 and will not be considered here because this study was undertaken to determine the effect of adding a thermal storage pond to a dry cooling system. 
When considering the thermal storage pond concept, the trade-off between the higher capital and operating costs associated with the thermal storage pond, and the savings in capacity and energy costs resulting from improvement in plant performance during hot weather are primary concerns. Problems exist in the evaluation of each component of the trade-off. The capital cost of the pond is influenced by site-specific factors, preventing a generally applicable, accurate cost estimate. Further, the capacity and energy savings are decisively influenced by ambient conditions and the method of determining capacity and energy savings.

The capital cost of the thermal storage pond will depend on pond location with respect to the power plant. The location will determine the length of piping runs to the pond, pump size and parasitic pumping power. The location will in turn be dependent on the plant site arrangement and local topography. Without a specific site and plant layout the capital cost estimate must be based on assumptions concerning local conditions. Ever-changing costs of equipment, labor, materials, and interest, as well as changing inflation rates, only add to the difficulties, and a common basis must be sought.

The capacity and energy savings resulting from adding a thermal storage pond to an all-dry cooling system depend on ambient conditions and the method of determining capacity and energy savings. The daily temperature cycle is required for determining cooling tower performance and the effect of the pond on plant performance. Because the ambient conditions are site-specific and vary from year to year, the selection of representative weather data is important.

Probably the most significant problem in estimating the capacity and energy savings associated with the thermal storage pond is the method of determining the loss of capacity during hot periods and the cost of replacement energy. The power plant lost capacity could be based for the hottest single hour, or some average of the hottest hours. The hottest hour could be determined from one, or several, years' data. In each case the method can radically change the calculated peak loss of capacity by the power 
plant. In addition, the cost of replacement energy can be estimated either as constant regardless of time of day, or as variable over the day with the highest cost occurring during the peak demand periods. Because the thermal storage pond reduces replacement energy during peak periods while increasing replacement energy during nonpeak periods, the second method is more favorable to the thermal storage pond concept.

The assumed solutions to these problems will be discussed in Sections 2.0 and 3.0. However, it should be remembered that the effects of a thermal storage pond are extremely site-specific; the results of this study must be considered in that light. Knowledge of the fundamental economics of the capacitive pond concept was sought in this research to see if it should be studied in detail for sites under consideration for dry cooling. 


\subsection{DESIGN BASE FOR DRY-COOLED PLANT WITH THERMAL STORAGE POND}

This section describes the design for a dry-cooled plant with a thermal storage pond. This design was used as the basis for the parametric studies documented in this report.

\subsection{GENERAL DESCRIPTION AND SITE ARRANGEMENT}

The heat rejection system of a power plant with dry cooling and a thermal storage pond can be viewed as consisting of three components:

- the condenser where waste heat is removed from the power plant working fluid

- the dry cooling tower where the waste heat is rejected to the atmosphere

- the thermal storage pond.

In a conventional dry cooling system, the circulating water enters the condenser and removes the waste heat from the power plant working fluid. The circulating water is heated in the process and the waste heat is finally rejected to the atmosphere in a water-to-air heat exchanger, the dry cooling tower. As the ambient temperature increases, the temperature of the circulating water entering the dry cooling tower must also increase to reject the same amount of waste heat to the atmosphere. As the circulating water temperature increases, the temperature of the working fluid (steam) in the condenser increases, in turn, this raises the back pressure on the turbine, consequently reducing $p l a n t$ output. Hence, when the ambient temperature increases, the plant output decreases.

In most of the United States the peak demand for power represents air conditioning load and occurs during the hotter times of the day; the minimum load occurs during the coolest time of the day (in the summer). Therefore, the peak demand for power and the peak plant generation are out of phase. The thermal storage pond is a method of increasing plant output during the hotter times of the day by utilizing the excess cooling capacity that exists during the cooler time of the day. 
A combined dry cooling system and thermal storage pond would operate in three modes: a cooldown, a heatup, and a pond-out-of-service mode. In a normal day the pond would be out of service but containing cool water until the projected peak demand period, during which the pond would be in service. Cool water from the pond would be supplied to the condenser, which would decrease back pressure and increase plant output. The heated water from the pond would then go to the dry cooling tower where it would be cooled. However, because of the high ambient temperature, the water could not be cooled to its original temperature and would be returned to the pond relatively hot. When all the cool water was removed from the pond, the pond would be taken out of service and the hot water would be stored until night. At night the pond would again be put in service to supply water to the condenser but the dry cooling tower would have excess capacity so that the pond water would be cooled and returned to the pond to provide the plant with cool water during the succeeding day.

From this description of the thermal storage pond operating cycle, it is apparent that the thermal storage pond system will consist of four main components: the supply piping from the dry cooling tower to the thermal storage pond, the pond, the pumping plant to return the circulating water from the pond to the condenser, and the return piping. Figure 1 presents a schematic of the thermal storage pond system.

Because the costs associated with each component are influenced by the location of the thermal storage pond in relation to the power plant condenser and the dry cooling tower, the assumed plant site layout is of some importance. The plant is assumed to have a site layout similar to that used in multiple-unit, coal-fired power plants. As shown in Figure 2, the 1 and in front of the plant is occupied by the switchyard. Pollution control equipment and coal storage are located behind the plant. This requires that the cooling towers and thermal storage pond be located to the side of the plant. Assuming an arrangement similar to that used in Reference 2, the dry cooling tower installation is located $500 \mathrm{ft}$ from the side of the plant. 


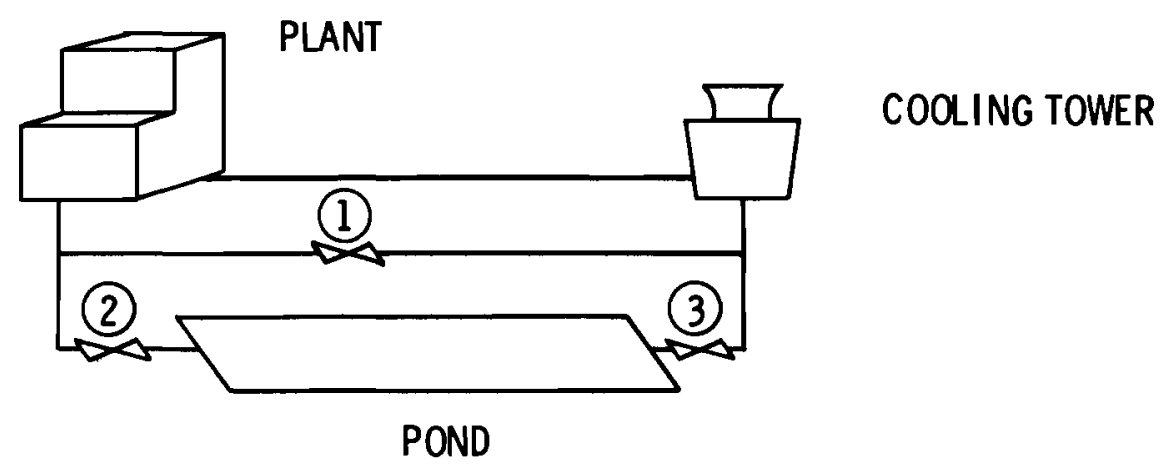

HEATUP MODE (13:00 T0 16:00)

1) VALVE 1 CLOSED, 2 AND 3 OPEN

2) COOL WATER IS SUPPLIED TO PLANT, HOT WATER IS RETURNED TO POND

POND OUT OF SERVICE MODE (16:00 TO 1:00 AND 4:00 TO 13:00)

1) VALVE 1 OPEN, 2 AND 3 CLOSED

2) POND OUT OF SERVICE

COOLD OWN MODE (1:00 T0 4:00)

1) VALVE 1 CLOSED, 2 AND 3 OPEN

3) HOT WATER IS SUPPLIED TO PLANT AND COOL WATER IS RETURNED TO POND

FIGURE 1. Thermal Storage Pond Concept 


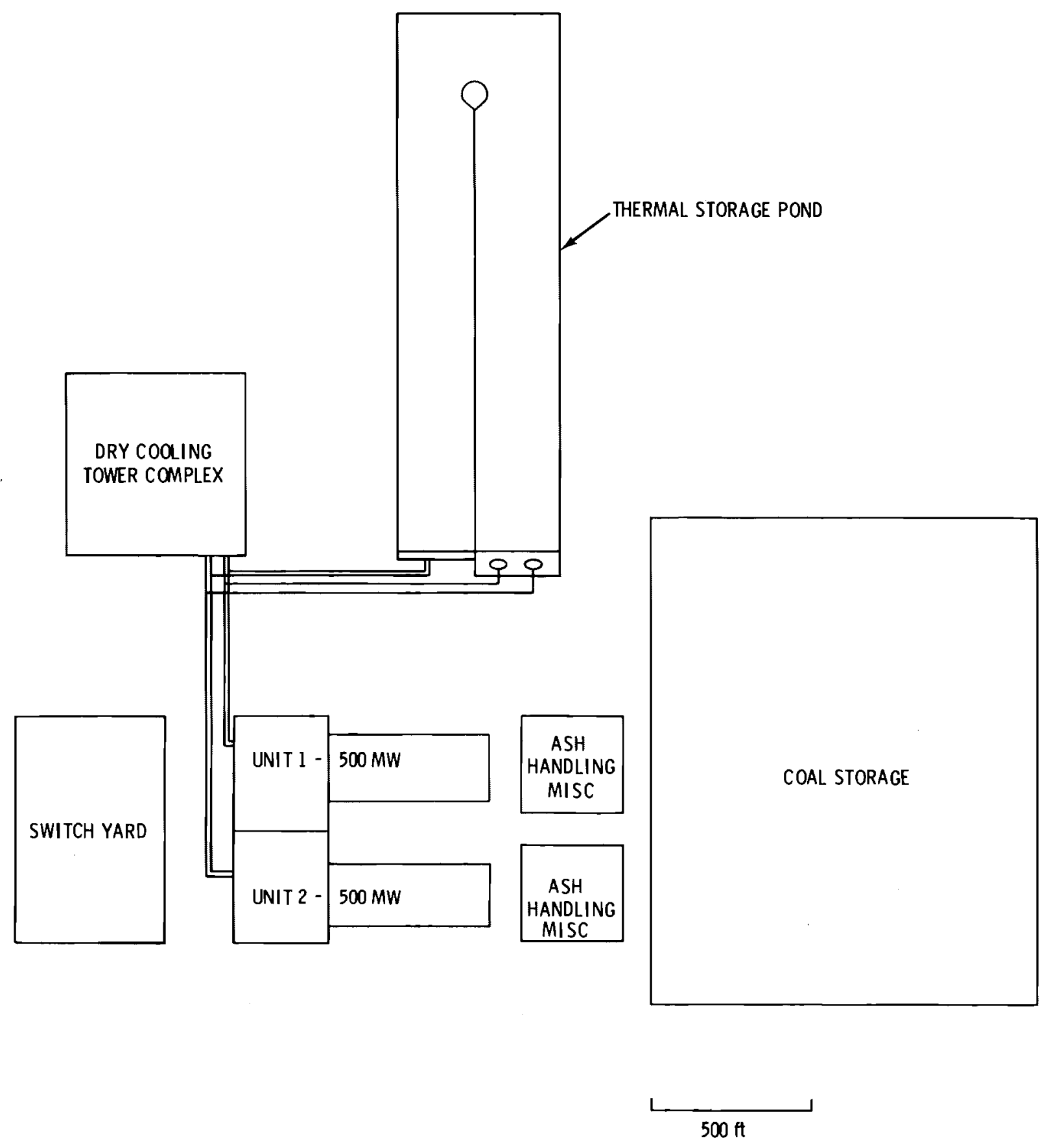

FIGURE 2. Conceptual Arrangement 
The location of the thermal storage pond is also dependent on site-specific factors, particularly topography, meteorology and site layout. For this study the cooling pond is assumed to be located $600 \mathrm{ft}$ downwind from the cooling towers. The distance between the cooling towers and the thermal storage pond is equivalent to three cooling tower diameters and was chosen to prevent the cooling pond from interfering with the performance of the dry cooling towers.

An alternative arrangement was considered, in which the pond was located next to the dry cooling tower pumping plant. This would reduce the cost of supply and return piping and might allow the use of the dry cooling tower circulating water pumps for both the dry cooling towers and the thermal storage pond. This arrangement was rejected for the base case because it was felt that site-specific factors would dictate the arrangement and it could not be assumed that the necessary land would be available, with suitable topography, for constructing a 50-acre pond, which would also be adjacent to the cooling tower. In addition, the thermal plume from the thermal storage pond could interfere with the performance of the dry cooling tower. This would be particularly true of an uncovered pond. The rule of thumb for cooling tower location is that three cooling tower diameters should separate each cooling tower to prevent interference. This approach was used in determining the spacing between the dry cooling tower and the thermal storage pond.

Because the arrangement of the cooling system components affects the economics of the thermal storage pond, it was chosen as one of the parameters to be studied in the parametric study of the thermal storage pond. Particularly, the lowest cost case, where the pond would be located adjacent to the dry cooling towers, was studied. The results are presented in Section 5.0 . 


\subsection{THERMAL STORAGE POND}

The thermal storage pond must have sufficient volume to provide the desired cooling capacity. In addition the pond must have hydrothermal characteristics which are not common to other storage ponds. The hydrothermal characteristics will determine the pond shape and the location of inlet structures and barriers. Finally, the requirement for an all-dry cooling system means that the pond must be both lined and covered. Each component of the pond design will now be discussed.

\subsubsection{Hydrothermal Characteristics}

The ideal pond would be designed so that, during the heatup and cooldown modes, the incoming water would not mix with the water already in the pond. This situation is designated "plug flow" and can potentially be realized because of the temperature difference between the incoming water and the water in the pond. The actual design of a plug flow thermal storage pond must encourage plug flow and prevent thermal short-circuiting of the pond, which would effectively reduce the pond storage capacity.

Guyer ${ }^{(1)}$ has modeled thermal storage pond performance and suggests that the optimal plug flow pond would have a depth of $15 \mathrm{ft}$ and a width of $218 \mathrm{ft}$, with the length determined by the desired storage capacity of the pond. To maintain plug flow, the pond must be equipped with eight horizontal barriers, each occupying one-half the cross-sectional area of the pond. The optimal number of barriers appears to be independent of pond length. Using these design requirements Guyer predicts that the effective storage capacity of the thermal storage pond would be $89 \%$ of actual pond capacity.

The model thermal storage pond used in this study differs from Guyer's pond design in two aspects. First, because the model pond will be constructed of lined earth rather than concrete (to minimize cost), the cross section will be different from that in Guyer's pond (Figure 3). The sides of the pond are assumed to have a 1:1 slope. This cross section produces a liner area and a cover area slightly different from those used by Guyer. 


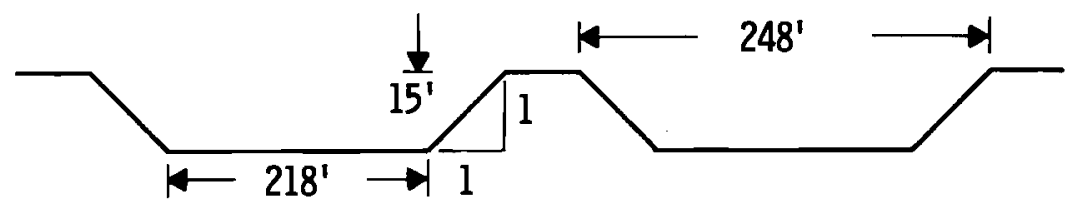

FIGURE 3. Pond Cross Section

The second variation in the model pond results from the pond being doubled back in a $U$ shape rather than straight as Guyer suggests. The piping requirements of the straight pond were excessive and the U-shaped pond produced a substantial reduction in capital cost. Because the U-shaped pond has not been model tested, there is no assurance that it will perform the same as a straight pond. However, in the absence of model test data it was assumed that the effective storage capacity of the U-shaped pond would also be $89 \%$ of actual pond capacity.

\subsubsection{Inlet Structure and Barriers}

The pond inlet structure is designed to produce a near-constant velocity profile from the top to the bottom of the pond, necessary to produce the desired plug flow. The inlet structure is assumed to consist of a concrete plenum with numerous penetrations in the pond side wall to allow proper distribution of the inlet water (see Figure 4).

The barriers consist of segmented reinforced concrete walls. The barriers occupy one-half the flow area of the pond; eight are evenly spaced along the pond length.

\subsubsection{Cover and Lining}

Because the primary advantage of a dry cooling system over other types of cooling is reduced water usage, it was felt that the water loss from the thermal storage pond must be reduced to a minimal level. The two primary mechanisms for water loss from a pond are seepage and evaporation; therefore the thermal storage pond must be lined and covered. 


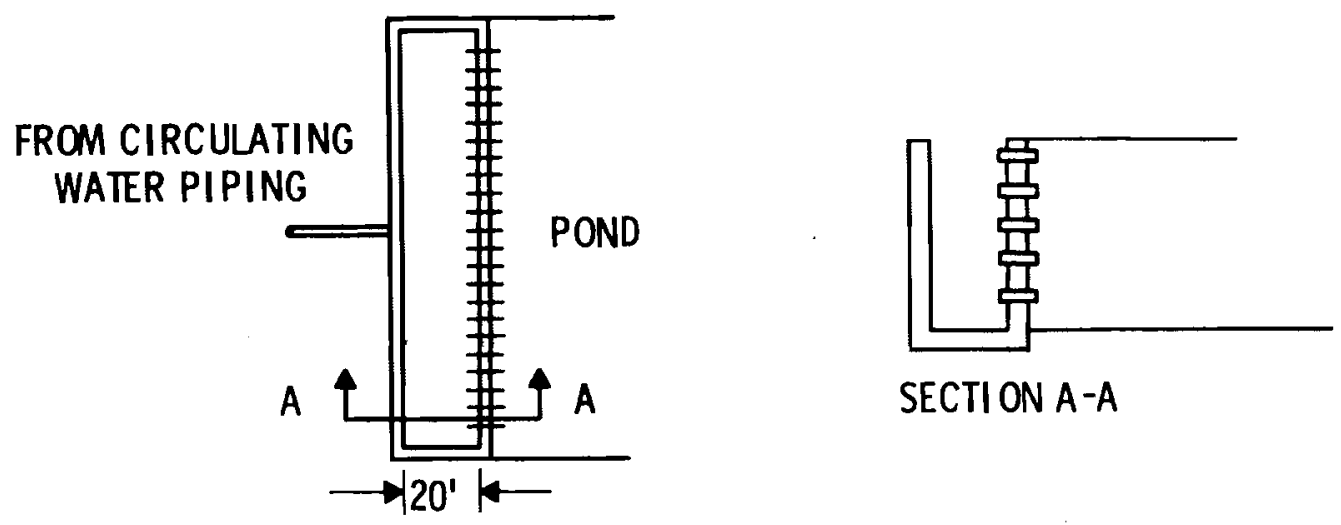

FIGURE 4. Inlet Structure

Guyer ${ }^{(1)}$ has surveyed potential pond lining material and recommends that a suitable pond liner for a thermal storage pond would be a synthetic butyl-rubber such as the DuPont Co. product Hypalon. Hypalon has a projected life of 40 years and is suitable for use at the pond operating temperature.

Based on his review of current cover technology, Guyer also recommends a pond cover system consisting of a floating flexible cover such as the patented "Roofloat" system. The cover is made of Hypalon and has a projected life of 40 years. In this study the Hypalon liner and floating flexible cover will be considered as the base case.

\subsection{PIPING SYSTEM}

The thermal storage pond piping system consists of three components: the supply piping, the pumping plant, and the return piping. To have a valid comparison with the previous dry cooling study, (2) all piping and pumping plant design characteristics of the thermal storage pond system were assumed to be the same as those used in Reference 2. A conceptual piping layout is shown in Figure 5.

\subsubsection{Pond Supply Piping}

The thermal storage pond supply piping includes the pipe and fittings from the cooling tower main circulation return piping to the inlet structure of the thermal storage pond. The piping is assumed to be steel pipe, entirely 


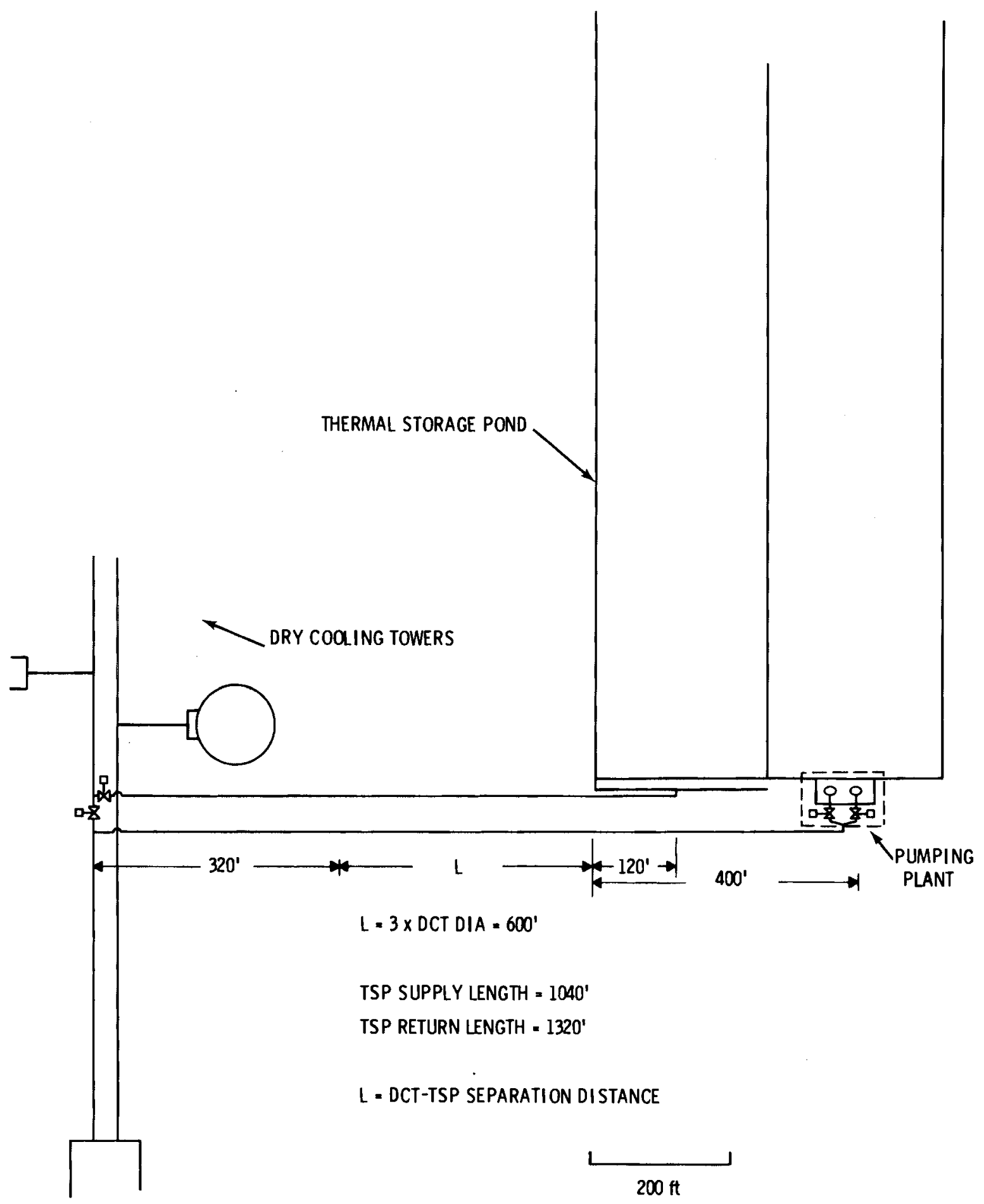

FIGURE 5. Conceptual Piping Layout 
underground. Appropriate ells, tees, and flanges are included, as is the motor-operated butterfly valve in the supply piping.

\subsubsection{Pond Return Piping}

The thermal storage pond return piping includes the pipe and fittings from the discharge of the thermal storage pond pumping plant to the cooling tower main circulation return piping. The piping is assumed to be steel pipe, entirely underground. Appropriate ells, tees, and flanges are included but the motor-operated butterfly valves are not included because they are part of the thermal storage pond pumping plant.

\subsubsection{Pond Pumping Plant}

The thermal storage pond pumping plant is located at the discharge end of the pond. It is assumed to be $50 \mathrm{ft}$ in length from the inlet of the pump bay to the pumping $p l a n t$ discharge. Two vertical pumps provide the required capacity. At the outlet of each pump is a motor-operated valve and an expansion joint. Other appropriate piping and fittings are included in the pump station. No auxiliary pumping capacity is provided. 


\subsection{METHODOLOGY}

This section describes the methodology used in the analys is of the thermal storage pond concept. Detailed descriptions of the pond capital cost model and annual performance model are included.

\subsection{COMPUTER PROGRAM}

The method for determining the economic viability of a dry cooling system with a thermal storage pond involved optimizing the dry cooling system with respect to incremental power cost and comparing this to the incremental power cost of an optimized dry cooling system without a thermal storage pond.

Several dry cooling concepts have been optimized in earlier studies ${ }^{(2)}$ using BNW-I, a Pacific Northwest Laboratory-developed computer program. The performance and cost characteristics of the thermal storage pond were added to the existing computer program for this study. This method has several benefits. First, a meaningful comparison among dry cooling concepts can be made because the same optimization and costing techniques will be used. Second, BNW-I included a more sophisticated simulation of the dry cooling system than is available in other thermal storage pond simulations.

BNW-I, discussed in detail in References 2, 3, and 4, will be briefly described there. The computer program consists of equations describing costs as a function of design and operating parameters, and physical models describing the interaction between the physical design and operating parameters. In addition, the program contains an optimization technique to determine which combination of internal dependent parameters results in the minimum incremental power production cost associated with dry cooling. For this study, BNW-I was modified by adding equations describing the costs of a thermal storage pond as functions of pond design and operating parameters. In addition the physical model describing the effect of the thermal storage pond on plant operations was included. Using the subroutines and parameters, 
the modified program optimization technique identifies the combined dry cooling tower/thermal storage pond system having the minimum incremental power production cost.

In Section 3.2, the pond design and cost model will be discussed. Section 3.3 describes the pond performance model. In all cases only the models related to the thermal storage pond will be discussed. See References 2,3 , and 4 for detailed discussions of the other aspects of BNW-I.

\subsection{POND DESIGN MODEL}

The pond design model consists of algorithms for sizing the thermal storage pond, the supply piping, the pond pumping plant and the return piping. The sizing is done by subroutine TSPDC, using assumed design conditions and variables calculated in BNW-I.

Using the design velocity, circulating water flow rate and water density calculated in BNW-I, TSPDC determines the required diameter of supply and return piping. It is assumed that pipe is available in size increments of 6 in. The next incremental pipe diameter, larger than the calculated pipe diameter, is selected as the supply and return piping diameter.

BNW-I contains cost data on piping and fittings as a function of system pressure, either $50 \mathrm{psi}, 75 \mathrm{psi}$ or $125 \mathrm{psi}$. The cost data, developed in Reference 5, are for steel pipe. All costs are in 1976 dollars. To assure that consistent costing techniques were used in both the conventional dry cooling and the thermal storage pond dry cooling study, the same piping cost data are used to estimate the supply and return piping cost.

The supply piping is assumed to consist of the underground steel supply piping, one motor-operated butterfly valve, one tee, one ell, and two $f l$ anges. The length of the supply piping is an externally specified variable. For the base case the supply piping is assumed to be $1100 \mathrm{ft}$ long.

The return piping is assumed to include the underground return piping, one tee, one ell and two flanges. The length of the return piping is an externally specified variable. For the base case the supply piping is assumed to be $1300 \mathrm{ft}$ long. 
Thermal storage pond size is determined by the desired storage capacity. The storage capacity is defined as the length of time (hours) of pond operation. Because the pond supplies all of the circulating water while it is in service, the required ideal pond volume is the product of the circulating water flow rate (in $1 \mathrm{bm} / \mathrm{hr}$ ) and the storage capacity (in $\mathrm{hr}$ ), divided by the density of water. The actual pond volume required to provide the specified storage capacity is larger than the ideal pond volume because of nonideal plug flow in the pond. To represent this effect the ideal pond volume is divided by the pond recovery efficiency. Based on model testing, ${ }^{(1)}$ the recovery efficiency is assumed to be $89 \%$. The pond cover area and liner area are calculated from the pond cross-section shape, discussed in Section 2.2.1.

The capital cost of the thermal storage pond is given by

$$
\begin{aligned}
\text { Pond capital cost } & =\text { (pond volume } \times \text { excavation cost }) \\
& +(\text { cover area } \times \text { cover cost }) \\
& +(1 \text { iner area } \times \text { liner cost }) \\
& +(\text { no. of barriers } \times \text { barrier cost }) \\
& + \text { inlet structure cost. }
\end{aligned}
$$

The excavation cost was taken from BNW-I and a value of $\$ 3.75 / \mathrm{yd}^{3}$ was used (1976 dollars). The costs of the liner and cover were taken from Guyer ${ }^{(1)}$ and escalated in 1976 dollars where necessary. An escalation rate of $9 \%$ per year was used. A liner cost of $\$ 0.75$ per $\mathrm{ft}^{2}$ and a cover cost of $\$ 2.00$ per $\mathrm{ft}^{2}$ were used in this study.

The barrier cost was estimated by calculating the excavation required by each barrier and then determining the volume of concrete and weight of rebar required by each barrier. The cost of excavation was assumed to be $\$ 3.75 \mathrm{per}$ $\mathrm{yd}^{3}$. The concrete was assumed to cost $\$ 60.2$ per $\mathrm{yd}^{3}$ and the rebar was assumed to cost $\$ 1172$ per ton. All costs were taken from the BNW-I code. The cost of one barrier was estimated to be $\$ 13,500$ (1976 dollars).

Inlet structure cost was estimated in a similar manner. The excavation and backfill were estimated from the volume of the structure. The volume of concrete was estimated from the volume of the inlet structure walls. The 
estimated rebar requirement was 0.0765 tons per $y d^{3}$ of concrete. The flow dispersing jets in the pond side wall were assumed to be 12-in. diameter concrete pipe mounted in the wall. All cost data from BNW-I include appropriate contractor overhead and profit.

The pumping plant cost was assumed to be the sum of the pump, the pumping plant piping, and the electrical costs. The cost of each component was estimated from an empirical equation relating cost to component operating conditions. These equations were developed for BNW-I and are discussed in Reference 5. The costs are in 1976 dollars.

The pumping plant parasitic energy use was estimated by calculating the pressure drop in the return piping and then calculating the horsepower necessary to pump the required flow rate, assuming a pump efficiency of $70 \%$.

\subsection{ANNUAL COST AND PERFORMANCE MODEL}

A dry cooling system with a thermal storage pond can operate in three modes: with the pond out of service, with the pond in service during the heatup mode, and with the pond in service during the cooldown mode. For determining plant performance and the incremental cost, the heatup and cooldown modes can be combined. Yearly operation can then be divided into two classes: the time period when the pond is in service and the time period when the pond is not in service. The algorithms to be used for each mode of operation will be discussed below.

The annual cost and performance models use a cumulative annual temperature profile and, particularly for this study, a profile was needed for the fraction of the year when the pond is out of service. This profile was developed by analyzing hourly temperature data for one year. Each hour was classified as "pond in service" or "pond out of service." Based on this classification, the temperature for the hour was included either in the cumulative annual temperature profile for the fraction of the year when the pond is in service or in the temperature profile for the fraction of the year when the pond is out of service. 
When sizing the pond, a storage capacity in hours of operation was specified. This is also the length of time that the pond is in service during either the heatup or cooldown mode. The daily temperature data were examined and the warmest period of hours was classified as the heatup mode; the coolest period of hours was classified as the cooldown mode. The warmup and cooldown modes were equal in length.

To include an hour's temperature in the "pond in service" cumulative temperature profile, a second criterion was also defined. During cold weather if the ambient temperature does not exceed the design ambient temperature (the highest ambient temperature at which the plant can produce its rated output) then nothing is gained by having the pond in service. In this case operating the pond would only increase parasitic pumping power without any corresponding improvement in plant performance. Therefore the second criterion is that the pond is not operated when the daily high temperature does not exceed the design temperature. In summation, an hour's temperature is included in the "pond in service" cumulative temperature profile if the hour occurs during the warmup or cooldown mode and if the high daily temperature exceeds the plant design temperature.

The BNW-I subroutine NOVART calculates the performance parameters of the plant and dry cooling tower over the yearly temperature profile. These, in turn, are used to calculate the incremental power production costs of the dry cooling plant. NOVART is called for each set of independent parameters, and the resulting incremental cost is the criterion used by the optimization routines. The performance of the power plant and dry cooling tower is determined as a function of the yearly temperature profile for the "pond in service" and "pond out of service". Because the analyses of the "pond in service" and "pond out of service" are different, they will be discussed separately.

\subsection{1 "Pond Out of Service" Model}

The model and algorithm for analyzing the "pond out of service" mode were discussed in Reference 3; only an abbreviated description will be included 
here. The algorithm for determining the incremental cost and plant performance with the pond out of service consists of calculations of the following variables performed in order.

1. Thermal efficiency of the turbine at the plant design point.

2. Thermal efficiency of the turbine at the rated back pressure.

3. Exit temperature of the steam turbine as a function of the ambient air temperature.

4. Total power output of the steam turbine for the particular ambient air temperature.

5. Power output of the plant to the electrical power transmission network for the particular ambient air temperature.

6. The difference between the power output of the plant and its rated power is determined and the cost of fuel for the gas turbine makeup power is calculated for the particular ambient air temperature.

7. Incremental cost of fuel for the steam supply system due to the steam turbine operating at off-design conditions.

8. Capital cost of the gas turbine used for makeup power, based on the plant performance during the hottest increment of the temperature profile.

9. Incremental cost of producing power at the particular ambient air temperature.

\subsection{2 "Pond In Service" Model}

Two methods of determining annual performance were considered in this study. The first method consists of calculating the plant and cooling tower performance on an hour-by-hour basis, then calculating an annual incremental power cost. The second method (actually used) is similar to that used in determining the plant performance with the pond out of service. A psuedo or transformed cumulative temperature curve was developed that included the ambient temperature during both the pond warmup and cooldown modes. The cumulative temperature curve was divided into increments, each of which would be analyzed. 
The hour-by-hour method avoids the assumptions necessary in developing a cumulative temperature curve, but has the disadvantage of requiring large amounts of computation time. In addition, this method assumes that one year's weather data are representative of the weather the plant will experience during its 30-year life. The addition accuracy of the hour-by-hour method only influences the calculation of the energy penalty. As Chapter 5 will show, the energy penalty is a relatively minor component of the incremental cost. It appears that a less sophisticated method of determining the energy penalty will not significantly influence the study results.

Because BNW-I already uses the cumulative temperature approach it was decided that this method would be used in simulating the thermal storage pond and dry cooling system. Using a cumulative temperature profile in simulating the thermal storage pond assumes that the daily temperature can be modeled as a periodic function with a relatively constant amplitude over a few periods. In this situation the thermal storage pond high temperature (temperature at the end of the heatup mode) and the pond low temperature (temperature at the end of the cooldown mode) can be determined.

Once the psuedo or transformed cumulative temperature profile was developed it was divided into increments. It was assumed that the high ambient temperature (temperature during heatup mode) and the low ambient temperature (temperature during cooldown mode) are constant throughout the increment at some mean value for each, as shown in Figure 6.

\subsubsection{Plant Performance Model}

From a heat balance on the plant and cooling tower system (Figure 7) it is obvious that

$$
\begin{aligned}
& \text { for heatup mode, } Q_{\text {in }}=Q D C T_{H}+W_{H}+\text { QSTORE } \\
& \text { for cooldown mode, } Q_{\text {in }}=Q D C T_{L}+W_{L}-\text { QSTORE }
\end{aligned}
$$




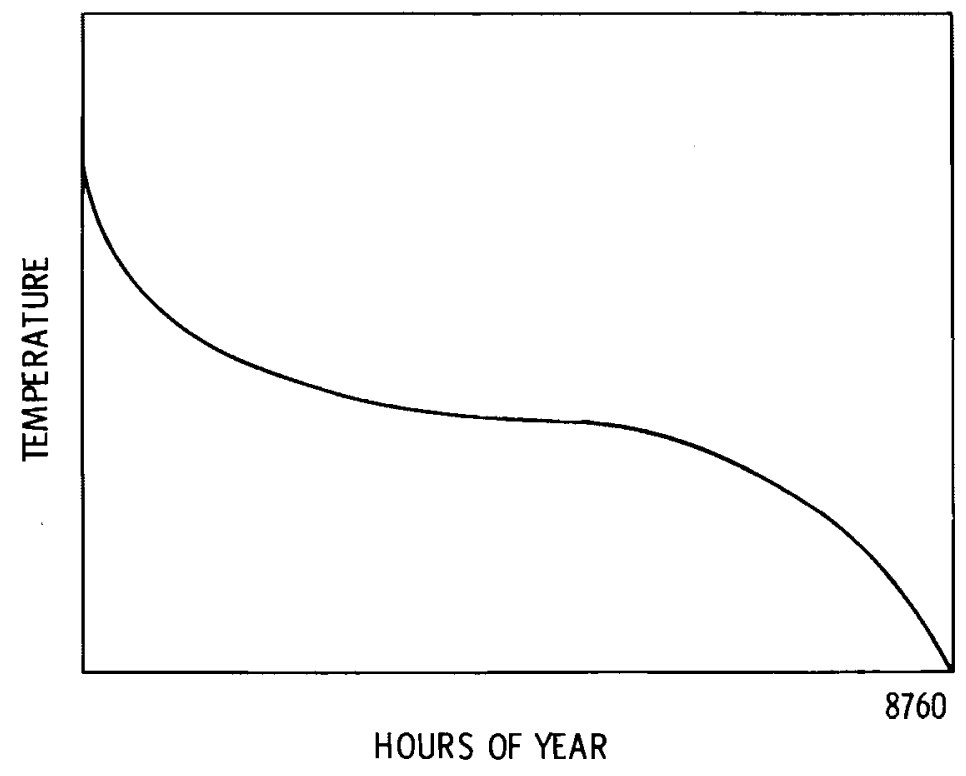

A. CUMULATIVE AMBIENT TEMPERATURE PROFILE

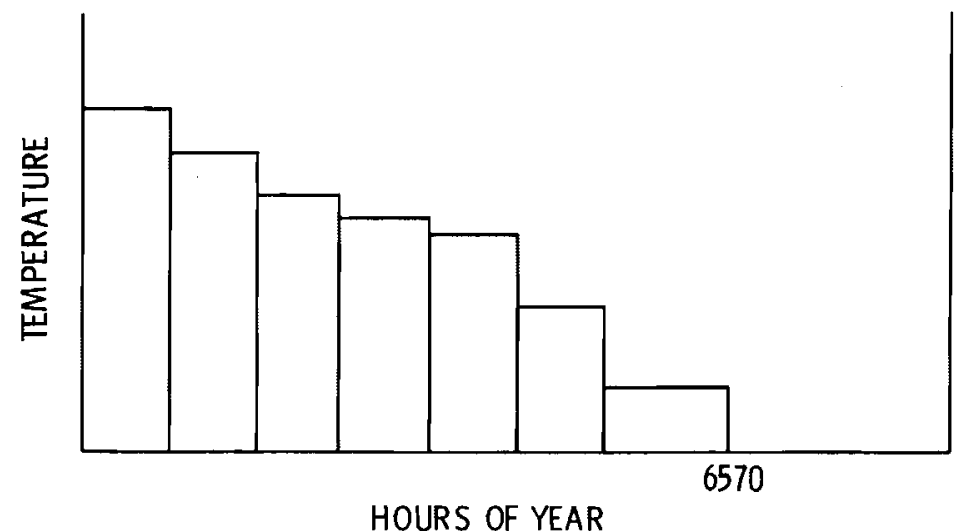

B. CUMULATIVE TEMPERATURE PROFILE FOR FRACTION OF YEAR WITH POND OUT OF SERVICE

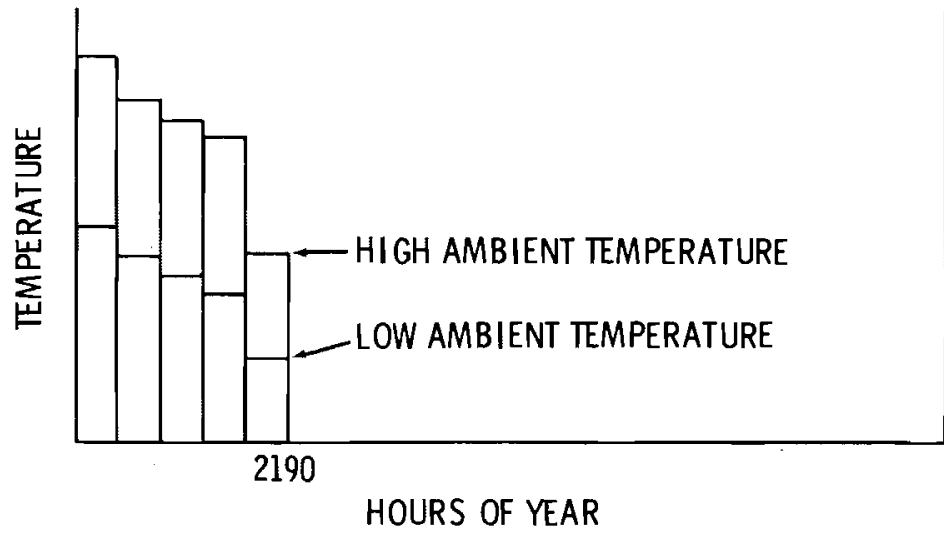

C. CUMULATIVE TEMPERATURE PROFILE FOR FRACTION OF YEAR WITH POND IN SERVICE

FIGURE 6. Cumulative Temperature Profiles 


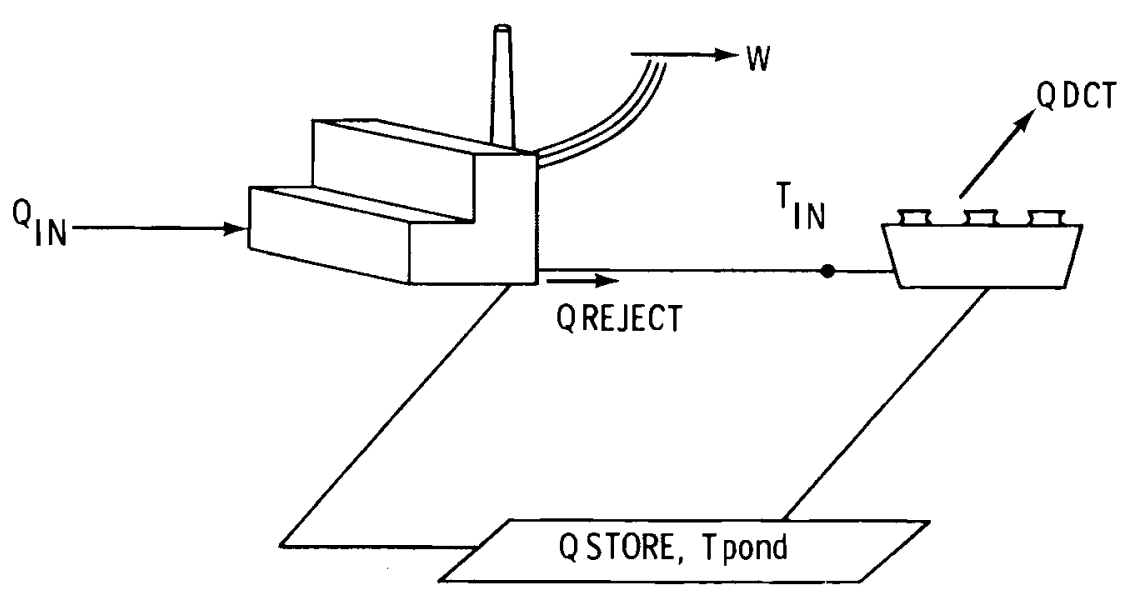

$\operatorname{Tamb}_{H}$ OR Tamb

FIGURE 7. Plant Heat Balance

The dry cooling tower performance can be expressed as heat exchanger effectiveness:

$$
\begin{aligned}
& \mathrm{QDCT}_{H}=E C_{\min }\left(T_{i n_{H}}-T_{a m b H}\right) \\
& \mathrm{QDCT}_{\mathrm{L}}=E C_{\min }\left(T_{i n_{L}}-T_{a m b L}\right)
\end{aligned}
$$

The inlet temperature to the dry cooling tower is related to the temperature of the pond water and the heat rejected by the power plant in the condenser.

$$
\begin{aligned}
& \left.T_{\text {in }(H)}=T_{\text {pondL }}+\text { QREJECT/(MFR }\right)\left(C_{p}\right) \\
& \left.T_{\text {in }(L)}=T_{\text {pondH }}+\text { QREJECT/(MFR }\right)\left(C_{p}\right)
\end{aligned}
$$


Substituting Equations (3) through (6) into Equations (1) and (2) yields

$$
\begin{aligned}
& M C_{p}\left(T_{\text {pondH }}-T_{\text {pondL }}\right)=Q_{\text {in }}-E C_{\min }\left(T_{L}+\frac{\text { QREJECT }}{(\text { MFR })\left(C_{p}\right)}-T_{\text {ambH }}\right)-W_{H} \\
& M C_{p}\left(T_{\text {pondL }}-T_{\text {pondH }}\right)=Q_{\text {in }}-E C_{\min }\left(T_{H}+\frac{\text { QREJECT }}{(\text { MFR })\left(C_{p}\right)}-T_{\text {ambL }}\right)-W_{L}
\end{aligned}
$$

Equations (7) and (8) can be solved iteratively to find the pond high and low temperature and the output during the heatup and cooldown modes.

\subsubsection{Plant Performance Algorithm}

The computer code determines the plant performance in the following sequence:

1. A pond low temperature is assumed.

2. Using the pond low temperature as the condenser inlet temperature, the turbine efficiency is calculated for the heatup mode.

3. Using the turbine efficiency, the amount of heat rejected in the condenser is calculated for the heatup mode and the circulating water exit temperature is calculated.

4. Using Equation (8), the pond high temperature is found.

5. Using the pond high temperature as the condenser inlet temperature, the turbine efficiency is calculated for the cooldown mode.

6. Using the turbine efficiency, the amount of heat rejected in the condenser is calculated for the heatup mode and the circulating water exit temperature is calculated.

7. Using Equation (7), the pond low temperature is found.

8. The calculated pond low temperature is compared to the assumed pond low temperature if they have not converged; a new value is assumed for the pond low temperature and the process is repeated. If the pond low temperatures have converged, the code continues to the incremental cost mode 1. 


\subsubsection{Incremental Cost Mode1}

The incremental cost of dry cooling with a thermal storage pond includes the capital items listed below:

- cooling system equipment and installation costs (including indirect costs such as profit, overhead and engineering)

- thermal storage pond equipment and installation costs (including indirect costs such as profit, overhead and engineering)

- increased steam supply system cost

- change in plant costs due to difference between the turbine rated back pressure and the turbine design back pressure

- gas turbine capital cost.

The incremental cost of dry cooling with a thermal storage pond includes three fuel costs:

- increased base plant fuel required for producing power for the pumps and fans

- difference in the amount of base plant fuel required for the dry-cooled plant versus that of the reference plant operating at $3.5 \mathrm{in}$. $\mathrm{Hg}$ back pressure

- gas turbine fuel.

Operation and maintenance costs are calculated as a percentage of the cooling system capital cost. As with BNW-I, no operating and maintenance costs are applied to the gas turbine. Items and related costs not included within these codes would include the cover gas system, the cooling system instrumentation costs and the cooling loop water treatment costs.

The incremental cost of dry cooling with a thermal storage pond is expressed in mills/kWh and given by

$$
C=\frac{F C R \text { (capital costs) }+ \text { Fuel Costs }+ \text { OM }}{C F \times 24 \times 365 \times 1000 \times P}
$$


where

FCR is the fixed charge rate

$O M$ is the operation and maintenance cost

CF is the capacity factor

$P$ is the power output.

A11 costs are in January 1976 dollars. Interest during construction and inflation prior to or during construction are not considered. Effects of the dry cooling system construction schedule and their impact on the balance of plant construction schedule are also not considered. The uncertainty involved in defining these items appears to outweigh any additional understanding obtained by their inclusion. Because the study is a comparative one, all options will be similarly affected.

\subsubsection{Incremental Cost Algorithm}

When the plant performance algorithm for a given temperature increment is completed, the subroutine NOVART executes the cost algorithm, consisting of the following steps:

1. Using the plant power generation calculated in the performance algorithm and taking into account the parasitic power consumption of the dry cooling system, the plant power output to the electrical power transmission network is calculated for the given ambient air temperature range.

2. The difference between plant rated size and actual power generation is calculated and the cost of fuel for the gas turbine makeup power is determined for the particular ambient air temperature range.

3. The incremental cost of fuel for the steam supply system due to turbine operation at off-design conditions is calculated for the particular ambient temperature range.

4. Using Equation (9), the incremental cost of producing power is calculated for the particular ambient temperature range.

To determine the incremental cost for the complete year simulated by the cumulative temperature curve, the incremental cost for each ambient temperature range is multiplied by the fraction of the year for which the 
ambient temperature range is valid. The resulting numbers are summed for both "pond in service" and "pond out of service", giving the total annual incremental cost of the dry cooling system.

\subsubsection{Discussion of Model}

The thermal storage pond influences the incremental cost of dry cooling in two ways. The capital cost of the thermal storage pond system increases the incremental cost of dry cooling while the reduction in the plant power generation penalty during peak temperatures tends to decrease the incremental cost of dry cooling by reducing the capital cost and fuel cost of the replacement gas turbine. Obviously the method of determining the capacity penalty (gas turbine capital cost) and energy penalty (gas turbine fuel cost) is important to the overall analysis of the dry cooling system economics.

In BNW-I the capacity penalty is based on the difference between the rated plant olitput and plant output during the average temperature for the hottest increment on the cumulative temperature curve. The hottest increment consisted of $0.15 \%$ of the temperature curve; i.e., the capacity penalty was based on the hottest 13 hours of the year. This method is reasonably close to that used in Reference 1, in which the maximum temperature of the 10 hottest days was used. This assumption should be considered when evaluating the results of this study. For example, a real utility may not feel that basing its reserve capacity on an average maximum temperature for 1 year's weather data is sufficiently conservative, particularly when the utility must meet its generation demand not only for just the hottest period of 1 year but for the hottest period that the plant will see in its 30 -year 1 ife.

The capacity penalty is also influenced by how the thermal storage pond is used. In this study the pond is assumed to operate on a fixed daily cycle. For a pond with a 3-hour storage capacity, the heatup mode might last from 14:00 to 17:00 and the cooldown mode from 2:00 to 5:00. In this case the maximum reduction in plant output would occur just before and just after the pond began the heatup mode (see Figure 8 ). 


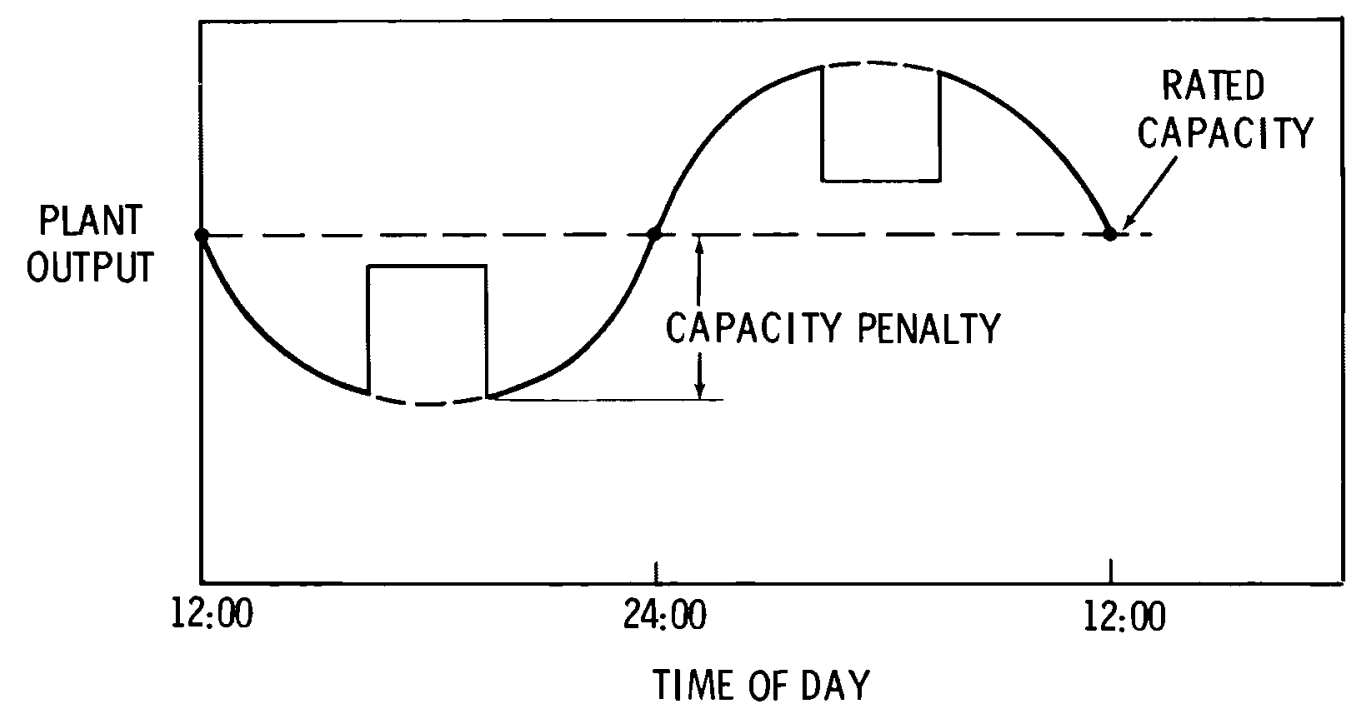

FIGURE 8. Plant Generation Profile with Pond on Fixed Daily Cycle

A second approach would be to bleed in the pond water and mix it with the return circulating water from the cooling tower. In theory, this would produce a plant generation profile similar to that shown in Figure 9. The elimination of the spikes that occur in the fixed cycle mode would tend to reduce the capacity penalty. This approach was rejected because of the difficulty in predicting ambient temperature. Without prior knowledge of the daily temperature profile, the rate of mixing pond water with cooling tower water cannot be determined. The cool water from the pond would possibly be used before the peak power reduction has been reached, producing the results shown in Figure 10.

The method of determining the energy penalty is also of some importance. In BNW-I, all replacement power is assumed to be provided by gas turbines; the energy penalty is based on the cost of gas turbine fuel. In general, the utility's cost for replacement power will depend on the time of day in which the power is required. During the peak demand period, replacement power would probably be provided by the expensive gas turbines; during off-peak hours, the replacement power may be provided by less expensive combined cycle or coal-fired intermediate-load plants. Because the thermal storage pond 


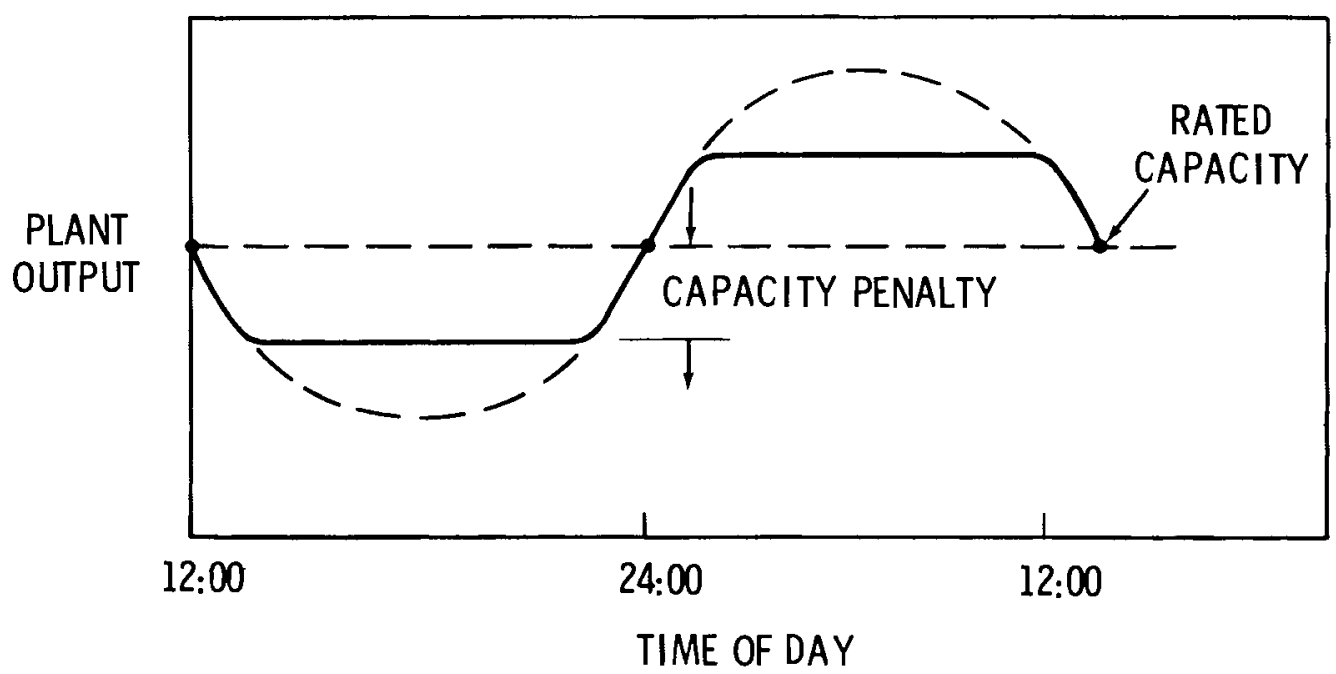

FIGURE 9. Plant Generation Profile with Ideal "Bleed-in" Cycle

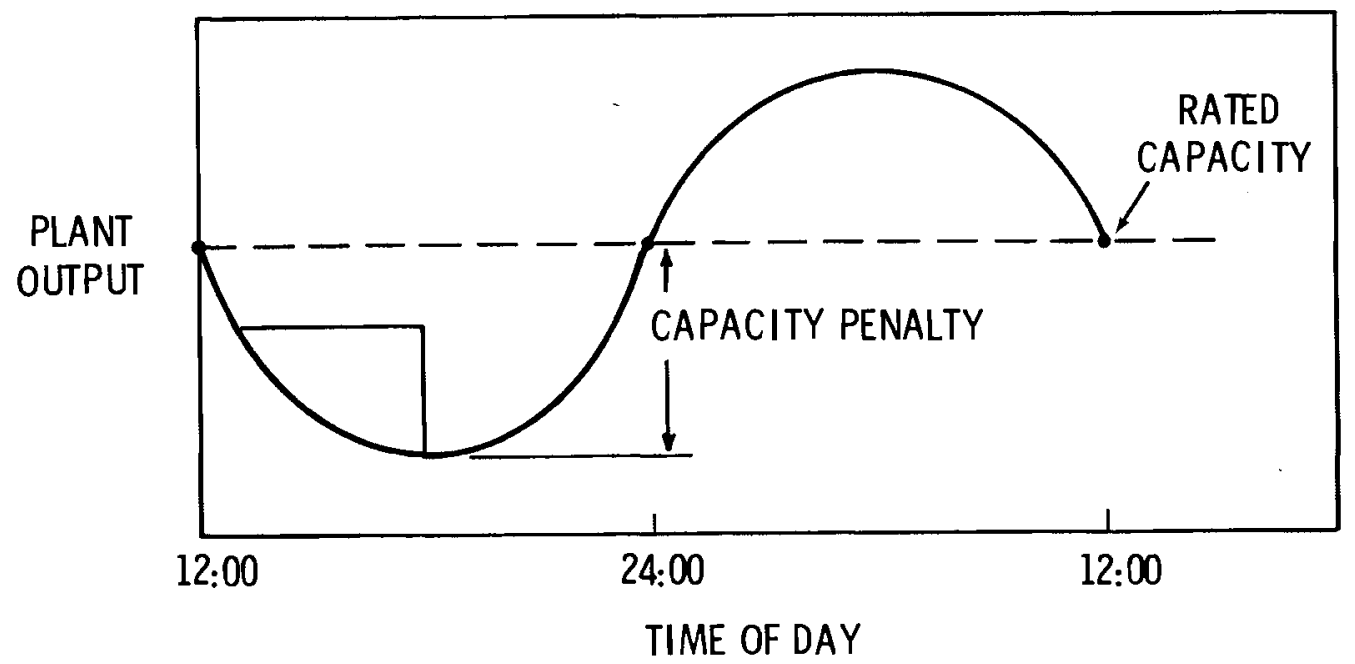

FIGURE 10. Plant Generation Profile with Failure To Predict Ambient Temper ature 
increased the plant output during peak demand periods but reduced plant output during off-peak periods, using the same charge for replacement energy penalizes the thermal storage pond concept.

For the baseline case the method used in BNW-I for determining replacement power cost was used. This allowed a valid comparison between the previous results and this study. As part of the parametric study a case was considered where the replacement power required in off-peak hours was considered to cost $10 \mathrm{mill} / \mathrm{s} / \mathrm{kWh}$ as compared to a peak power cost of 24 $\mathrm{mills} / \mathrm{kWh}$. 


\subsection{COOLING SYSTEM DESIGN BASES}

The general design bases and limitations used in this study are the same as those used in Reference 2. They will be described in this section.

\subsection{GENERAL DESIGN BASIS}

The primary purpose of this study was to compare a dry cooling system that included a thermal storage pond with three other cooling concepts described in Reference 2 in terms of incremental power production costs. An objective comparison requires that the systems be optimized, and that the bases for the cooling system design be equitable for each system. The parameters, system options and limitations shown in Table 1 were used because they had been selected for the previous study. (2) While they are equitable for the three systems studied in Reference 2, it is not clear that the design basis, particularly meteorology, is equitable for the thermal storage pond system. The effect of varying site meteorology along with other parameters will be discussed in Section 5 .

The comparison of the three systems discussed in Reference 2 with the thermal storage pond system and the parametric analysis of each individual system were based upon the conditions listed in Table 1. However, to determine if the bases were equitable for each system, and to perform additional parametric analysis for each individual system, the effect of varying these general design bases was investigated. The effect of these factors is discussed in Section 5 .

\subsection{ADDITIONAL DESIGN BASIS LIMITATIONS}

The comparison of the three systems presented in Reference 2 with the thermal storage pond system is greatly simplified if some design and operating parameters of the resulting optimized cooling system are the same or nearly so. This allows the investigator to concentrate on the major differences, and 
TABLE 1. Design Basis

\begin{tabular}{|c|c|}
\hline Parameters & Options and Limitations \\
\hline Plant Type & Fossil \\
\hline Plant Size & $1000 \mathrm{MWe}$ \\
\hline Nominal Heat Rejection & $5.1 \times 10^{9} \mathrm{Btu} / \mathrm{hr}$ \\
\hline Reference Base Plant Cost & $440 \$ / k W e$ \\
\hline Base Plant Fuel Cost & $81 \$ / 10^{6} \mathrm{Btu}$ \\
\hline $\begin{array}{l}\text { Base Plant Incremental Steam } \\
\text { Supply Cost }\end{array}$ & $146 \$ / \mathrm{kWe}$ \\
\hline Capacity Charge & $121 \$ / \mathrm{kWe}$ \\
\hline Energy Charge & $24 \$ / k W h$ \\
\hline Capacity Factor & $65 \%$ \\
\hline Fixed Charge Rate & $17.4 \%$ \\
\hline Cooling System Annual 0\&M & $\begin{array}{l}\text { Annual cost equals } 1 \% \text { of cooling } \\
\text { system capital cost }\end{array}$ \\
\hline Meteorological Site & Wyodak, Wyoming \\
\hline Turbine Type & $\begin{array}{l}\text { Modified Conventional } \\
\text { (Maximum back pressure } 8 \text { in. Hga) }\end{array}$ \\
\hline Design Temperature & $50^{\circ} \mathrm{F}$ \\
\hline Condenser Type & Surface Single-Pressure \\
\hline Tower Arrangement & Circular \\
\hline Heat Exchanger Orientation & Vertical \\
\hline Cooling System Type & Indirect Mechanical Draft \\
\hline Fan Draft & Induced \\
\hline Fan Discharge & Recovery Stack \\
\hline $\begin{array}{l}\text { Ratio: Tower Roof Area/ } \\
\text { Fan Swept Area } \\
\text { (Packing Factor) }\end{array}$ & 20 \\
\hline Plant Operating Conditions & Full Load, Valve Wide Open \\
\hline
\end{tabular}


to readily determine which systems are generally better and why. Analysis indicated that placing the following limits on the three different systems will still permit determination of near optimal designs.

- Tower diameter - $19510 \mathrm{ft}$

- Heat exchanger tube length - $80 \mathrm{ft}$

- Fan diameter - $28 \mathrm{ft}$. 


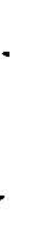




\subsection{RESULTS}

This section presents the results of the trade-offs between various parameters. The trade-offs refer to the scheme by which the optimization code determines the least-cost cooling system design. For a given set of external variables which include the design basis parameters, the trade-offs will determine the combination of internal optimized parameters resulting in the lowest overall costs. The results of the optimization for Wyodak, Wyoming and Phoenix, Arizona meteorology are presented in Figure 11. An overview of the results of the parametric study is presented in truth table matrix form in Figures 12, 13 and 14, showing the effects of various parameters on the incremental power cost (while holding other parameters constant).

\subsection{GENERAL CONSIDERATIONS}

In the parametric study, the impact of variations of significant parameters on the economic analysis of the thermal storage pond dry cooling system was to be investigated. The method by which any one parameter was evaluated was to fix all the other variables according to the design base values. The parameter being studied would then be varied over the entire range. Each significant variable was studied in this manner. The design base conditions are discussed in Chapter 4.

In this section, different optimized designs are presented for comparison. A cost summary for each optimized design is included. The costs are given in terms of unit energy costs. The unit energy cost of the capital cost items is determined from

$$
\text { Unit Energy Cost }=\frac{\text { Capital Cost } \star \text { Fixed Charge Rate }}{\text { PTant Size } \star \text { Capacity Factor } \star \text { Hours per Year }} .
$$

The capital cost items include the cooling system, the capacity charge, and the base plant scaling. The cooling system includes the condenser, the piping system and pumps, cooling tower, and, in some cases, the thermal storage 

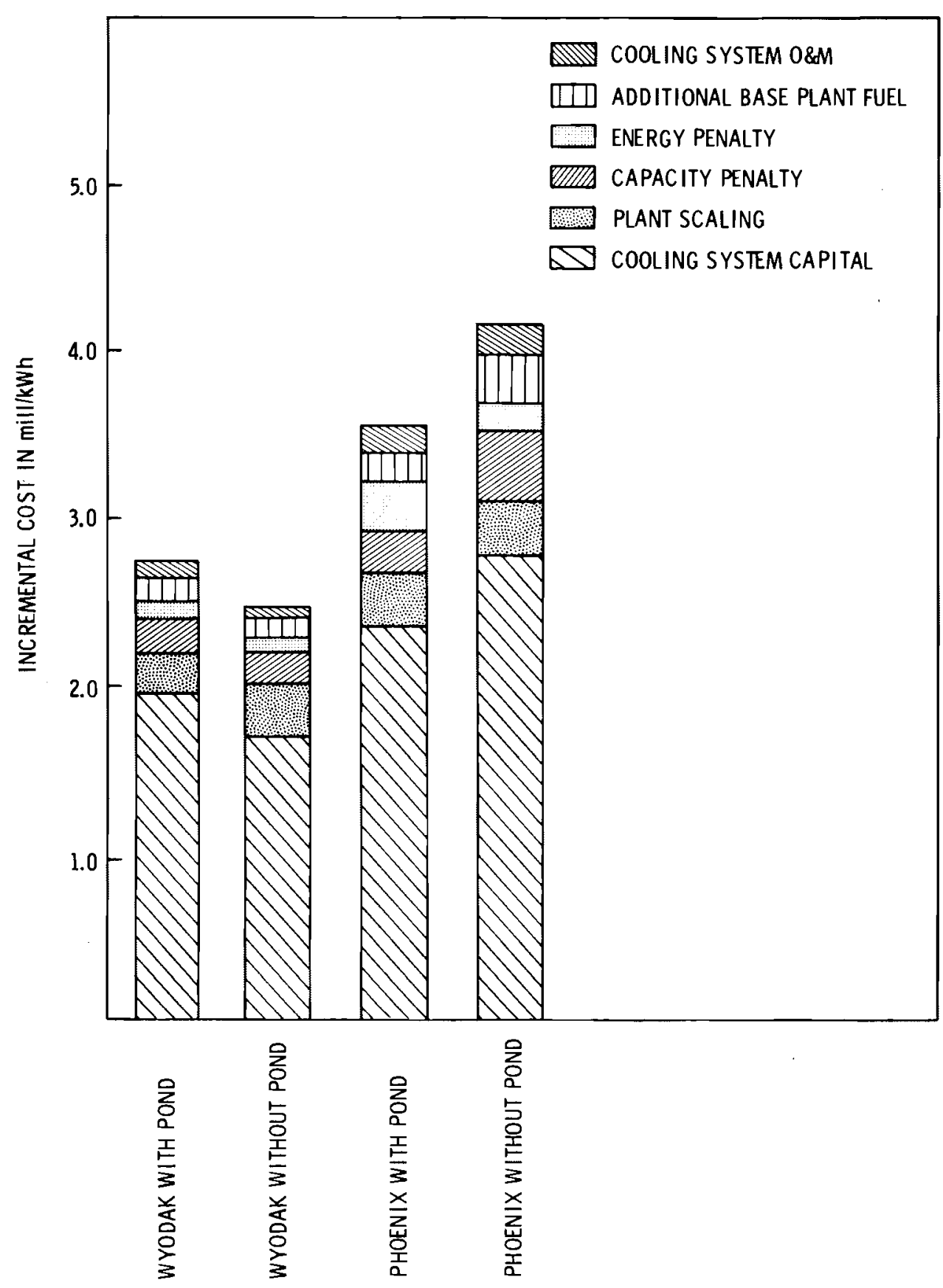

FIGURE 11. Comparison of Incremental Power Production Costs 
$\omega$

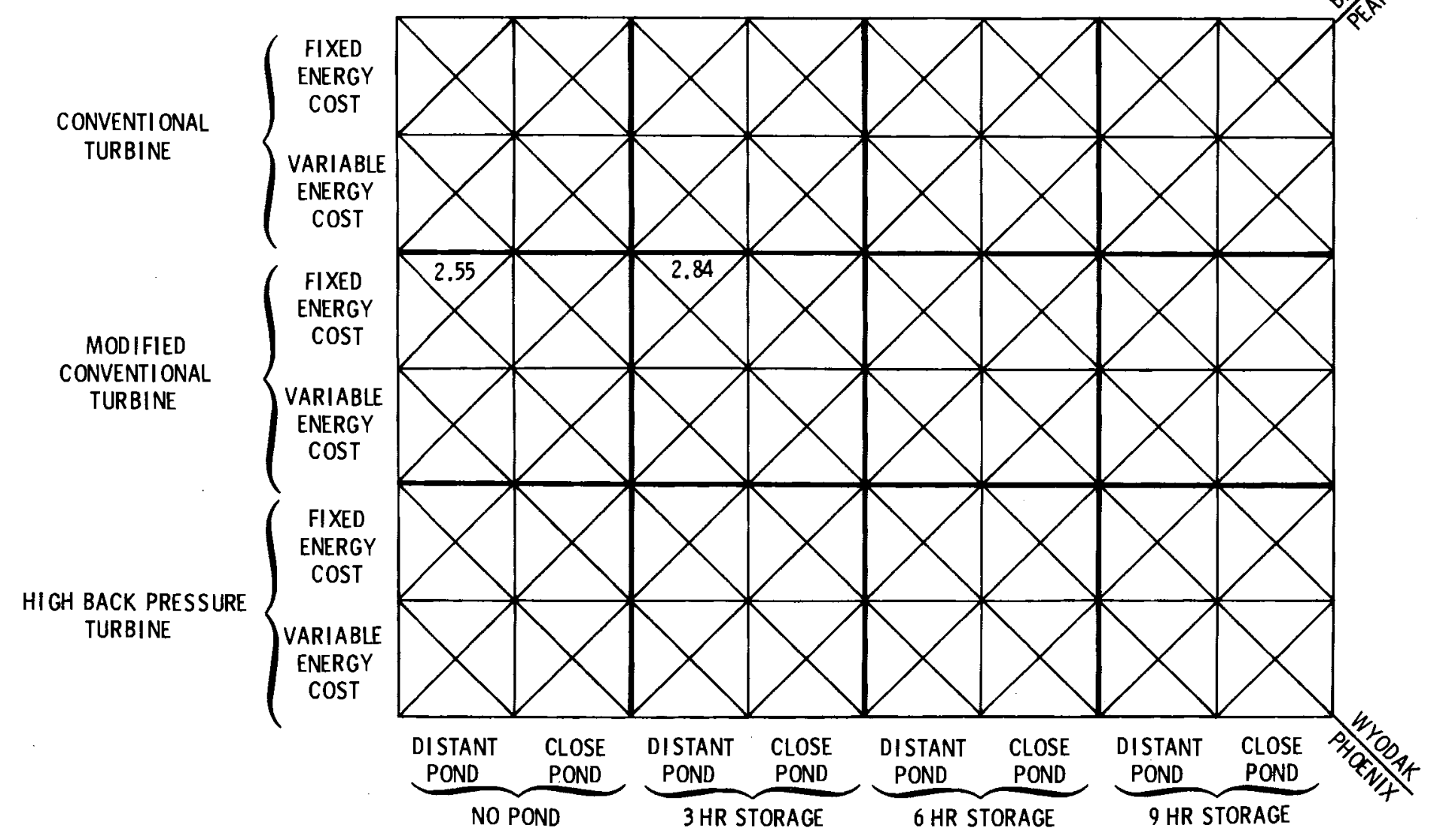

FIGURE 12. Parametric Study Incremental Power Cost, mi11s/kWh (Design Temperature of 300F) 


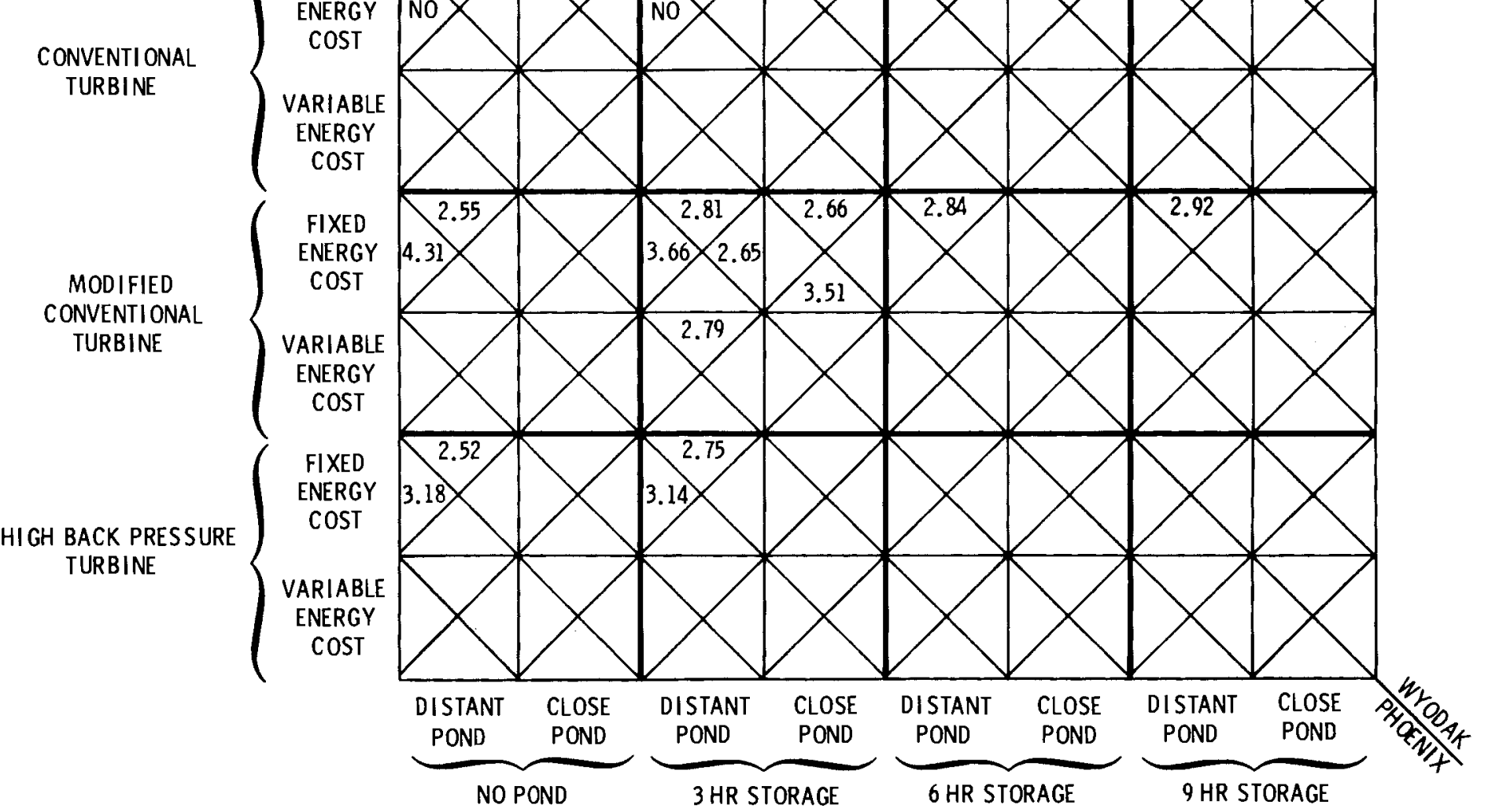

FIGURE 13. Parametric Study Incremental Power Cost, mills/kWh (Design Temperature $50 \mathrm{~F}$ ) 


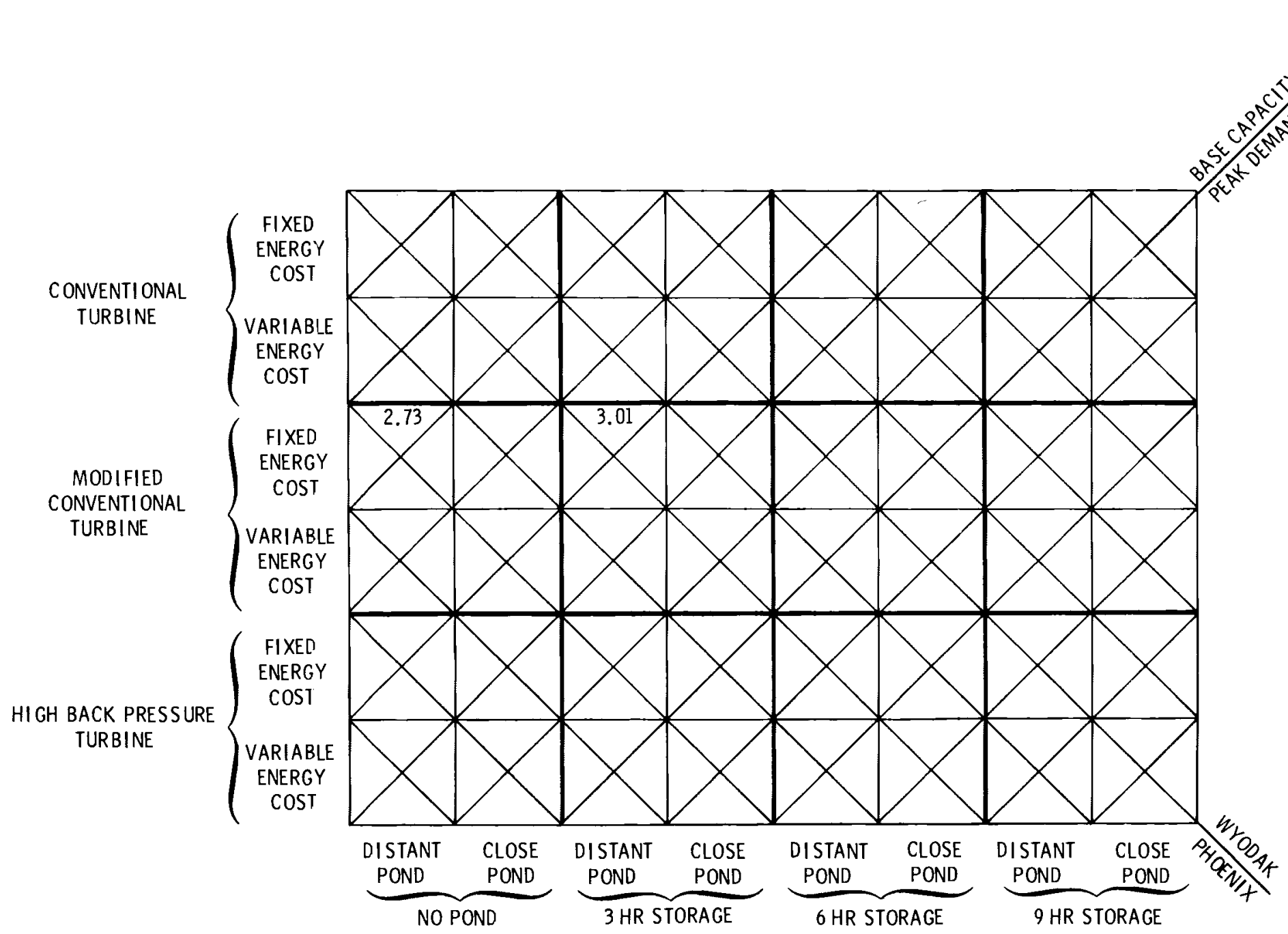

FIGURE 14. Parametric Study Incremental Power Cost, mi11s/kWh (Design Temperature $70^{\circ} \mathrm{F}$ ) 
pond. The capacity cost is the capital cost of the gas turbine required to make up lost performance on the hottest $0.15 \%$ of the year. Base plant scaling refers to the cost of adjusting the plant size to account for turbine back pressure and its heat rate effects. Scaling also includes the cost of increasing the plant size to provide power for the fans and pumps. The energy cost is the cost of fuel for the gas turbine. The base fuel cost is the cost of additional fue $i$ needed to provide auxiiiary power to the fans and pumps and to account for turbine heat rate effects. The annual operating and maintenance cost is assumed to be $1 \%$ of the cooling system capital cost. It is estimated on a unit energy cost basis except that the fixed charge rate is not included.

\subsection{TURBINE TYPE}

When selecting a turbine for a dry cooling system, three types are usually considered: the conventional turbine, the modified conventional turbine and the high back pressure turbine. All three types exhibit the same behavior as the turbine back pressure is increased. In each case the turbine heat rate increases as back pressure increases. Because of this, to achieve a given amount of electric output at a given ambient temperature, a plant with increased back pressure must burn more fuel. The increased heat rate will also result in a requirement for a larger steam supply system. Operating at a higher back pressure does have the advantage of increasing the initial temperature difference between the inlet water temperature and the inlet air temperature in the dry cooling tower heat exchanger. The cooling system size decreases as the initial temperature difference increases. Therefore, increasing back pressure results in a trade-off between plant capital and fuel cost and the cooling system cost. Earlier studies have shown that the trade-off favors turbines capable of operating at increased back pressure. Reference 2 investigated turbine optimization using the BNW-I computer code and has concluded that the high back pressure type turbine is the least cost turbine for the situations studied. 
In this study the effect of the thermal storage pond on turbine selection was studied. As in Reference 2, the conventional turbine, the modified conventional turbine and the high back pressure turbine were considered as candidates.

\subsubsection{Conventional Turbine}

The conventional turbine is widely used and its performance characteristics are well established. The operating back pressure range is typically about 2 to $5 \mathrm{in}$. Hga with the rated output at $3.5 \mathrm{in.} \mathrm{Hga.} \mathrm{The}$ conventional turbine is the most efficient type and consequently has the lowest heat rate. The conventional turbine has the disadvantage of being unable to operate at back pressures above 5 in. Hga.

\subsubsection{Modified Conventional Turbine}

A conventional turbine can be modified so that it can operate with a back pressure varying between 2 to $14 \mathrm{in.} \mathrm{Hga.} \mathrm{The} \mathrm{modified} \mathrm{conventional} \mathrm{turbine}$ at its rated back pressure of $3.5 \mathrm{in}$. Hga would have a heat rate approximately $1 \%$ higher than the conventional turbine. It appears that problems with off-design aerodynamics at the low pressure end of the turbine will limit the turbine operating range to below 8 in. Hga.

\subsubsection{High Back Pressure Turbine}

Specially designed high back pressure turbines are also available. These turbines can operate between 5.0 and $15.0 \mathrm{in}$. Hga with the rated conditions at $8.0 \mathrm{in.} \mathrm{Hga.} \mathrm{The} \mathrm{high} \mathrm{back} \mathrm{pressure} \mathrm{turbine} \mathrm{has} \mathrm{the} \mathrm{disadvantage} \mathrm{of} \mathrm{a}$ substantially higher heat rate at lower back pressures than either the conventional turbine or the modified conventional turbine. Unlike the modified conventional turbine, high back pressure turbines have been built and are in operation.

\subsection{TURBINE OPTIMIZATION ANALYSIS}

The optimization analysis was performed for the three turbine types for the base case, assuming a 1000 MW fossil-fueled power plant located at Wyodak, Wyoming. In optimizing the turbine, only the impact on the cost of dry 
was considered. Any cost variations among turbine types were not included. While the cost of the conventional and modified conventional turbine should be approximately equal, the high back pressure turbine may be up to $15 \%$ more expensive. This will tend to decrease the attractiveness of the high back pressure turbine.

The results of the analysis are presented in Tables 2 and 3 . For the assumed Wyodak meteorology the high back pressure turbine is the optimal choice for dry cooling systems, both with and without a thermal storage pond. In addition, no turbine type results in the incremental cost of dry cooling with a storage pond approaching the cost of dry cooling without a thermal storage pond.

\subsection{POND STORAGE}

One important variable in determining the thermal storage pond cost and performance is the pond storage capacity in hours of plant operation. As the pond storage capacity increases, the cost of the pond also increases. However, the plant performance should also increase as the capacity and energy penalth are decreased by using larger ponds. To determine the optimal pond size, several cases were considered in addition to the base case, which includes a pond with a storage capacity of 3 hours of plant operation. Pond storage capacities of 6 hours and 9 hours were also tested. Storage ponds with a storage capacity of less than 3 hours are undesirable because the period of peak temperature often exceeds 1 or 2 hours, in which case the pond would not substantially reduce the peak lost generation. Ponds with a storage capacity greater than 9 hours would not have an interim period between pond operation sufficient to allow for complete mixing of the pond water.

The results of the dry cooling system optimization for pond storage capacities of 3,6 , and 9 hours are presented in Table 4 . The results indicate that, for the base case conditions, including Wyodak meteorology, the smaller pond has the lowest incremental cost. A storage capacity of 3 hours is used throughout if not otherwise specified. 
TABLE 2. Cost Summary by Turbine Type for Dry-Cooled Plant Without Thermal Storage Pond for Wyodak

Turbine Type Modified High Back

Capital Cost Summary

Tower

Piping

Condenser

Pond

Capacity Penalty

Plant Scaling

Total Capital Cost

Unit Energy Cost Summary

Total Capital Cost

Energy Penalty

Additional Base Plant Fuel

Operation and Maintenance

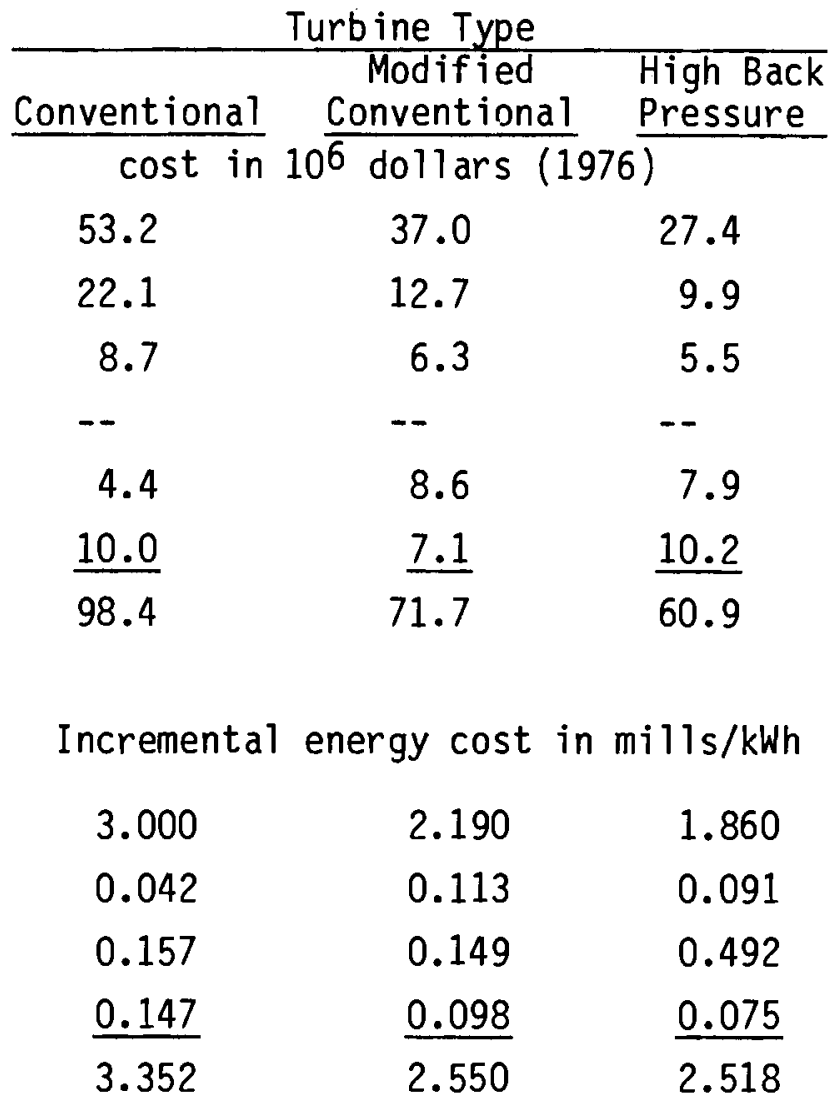


TABLE 3. Cost Summary by Turbine Type for Dry-Cooled Plant With Thermal Storage Pond for Wyodak

\begin{tabular}{|c|c|c|c|}
\hline \multirow[b]{2}{*}{ Capital Cost Summary } & \multicolumn{3}{|c|}{ Turbine Type } \\
\hline & Conventional & $\begin{array}{c}\text { Modified } \\
\text { Conventional }\end{array}$ & $\begin{array}{l}\text { High Back } \\
\text { Pressure }\end{array}$ \\
\hline & \multicolumn{3}{|c|}{ cost in $10^{6}$ dollars $(1976)$} \\
\hline Tower & 51. & 35.7 & 27.3 \\
\hline Piping & 20.4 & 12.0 & 9.2 \\
\hline Condenser & 8.7 & 6.2 & 5.3 \\
\hline Pond & 15.5 & 9.9 & 8.2 \\
\hline Capacity Penalty & 4.3 & 8.4 & 7.7 \\
\hline Plant Scaling & 8.4 & 7.2 & $\underline{10.3}$ \\
\hline Total Capital Cost & 109.0 & 79.4 & 68.0 \\
\hline Unit Energy Cost Summary & \multicolumn{3}{|c|}{ Incremental energy cost in $\mathrm{mills} / \mathrm{kWh}$} \\
\hline Total Capital Cost & 3.333 & 2.428 & 2.080 \\
\hline Energy Penalty & 0.034 & 0.121 & 0.093 \\
\hline Additional Base Plant Fuel & 0.133 & 0.150 & 0.492 \\
\hline \multirow[t]{2}{*}{ Operation and Maintenance } & 0.169 & 0.112 & 0.088 \\
\hline & 3.669 & 2.811 & 2.753 \\
\hline
\end{tabular}


TABLE 4. Dry Cooling System Optimization for Three Pond Storage Capacities for Wyodak

Capital Cost Summary

$$
\text { Tower }
$$

Piping

Condenser

Pond

Capacity Penalty

Plant Scaling

Total Capital Cost

Unit Energy Cost Summary

Total Capital Cost
Energy Penalty
Additional Base Plant Fuel
Operation and Maintenance

Pond Size

\begin{tabular}{|c|c|c|}
\hline 3-Hour & $6-\mathrm{Ho}$ & 9-Hour \\
\hline $\cos t$ &.$\overline{6 \mathrm{do}}$ & $(\overline{1976)}$ \\
\hline 35.7 & 33.4 & 31.7 \\
\hline 12.0 & 11.4 & 11.3 \\
\hline 6.2 & 6.1 & 6.0 \\
\hline 9.9 & 13.9 & 18.0 \\
\hline 8.4 & 8.3 & 7.9 \\
\hline 7.2 & 6.9 & 7.0 \\
\hline 79.4 & 80.0 & 81.9 \\
\hline
\end{tabular}

Incremental energy cost in mills/kWh

$\begin{array}{lll}2.428 & 2.439 & 2.500 \\ 0.121 & 0.143 & 0.163 \\ 0.150 & 0.142 & 0.143 \\ \frac{0.112}{2.811} & \underline{0.114} & \underline{0.117} \\ 2.838 & 2.923\end{array}$




\subsection{ENERGY COST}

There are several methods for estimating the cost of replacement energy. In the parametric study the sensitivity of the results to alternate methods of estimating replacement energy costs was investigated.

In BNW-I, replacement energy was assumed to be supplied from a gas turbine regardless of time of day or system load. The result is that replacement energy cost is constant at $24 \mathrm{mills} / \mathrm{kWh}$. In actuality a utility would have a variable cost for replacement energy. The expensive electrical energy generating facilities, such as gas turbines, would only be operated during periods of peak load. At off-peak conditions the replacement energy would probably be supplied from less expensive intermediate load facilities such as coal-fired power plants. Using a constant cost of replacement energy tends to penalize the thermal storage pond concept.

The thermal storage pond increases the plant output during the hot part of the day by supplying colder circulating water than the turbine would normally receive. The plant output is, in turn, decreased during the cool night when the pond supplies warmer circulating water to the turbine. Using a constant cost of replacement energy makes the capacity lost during the off-peak evening just as valuable as the capacity gained during the peak condition. For an actual utility the capacity gained during the peak period is of substantially more value.

A case was run to include variable replacement energy cost for the "pond-in-service" mode. The replacement energy during the warmup mode (corresponding to the last peak) was assumed to be supplied by a gas turbine at a cost of $24 \mathrm{mills} / \mathrm{kWh}$. The replacement energy during the cooldown mode (off-peak conditions) was assumed to be supplied by a coal-fired plant at a cost of $10 \mathrm{mills} / \mathrm{kWh}$.

BNW-I uses one constant value for the cost of replacement energy. To determine a meaningful constant value, the average cost of replacement energy was needed. The cost of replacement energy was assumed to be a sine wave with a period of 24 hours and a high energy cost of $24 \mathrm{mills} / \mathrm{kWh}$ and a low energy 
cost of $10 \mathrm{mills} / \mathrm{kWh}$. The amount of replacement energy (the plant rated output minus the power actually generated) was also assumed to be a sine wave with a maximum short fall of 40 MWe and a minimum short fall of zero. The product of replacement energy cost and amount of replacement energy was integrated over a year and the average cost of replacement power was determined by dividing by 8720 hours. The average cost was calculated to be $20.5 \mathrm{mills} / \mathrm{kWh}$.

Two situations were considered in the parametric study: the base case and the variable replacement power cost case. From these results, summarized in Table 5, it appears that using a variable replacement power cost does reduce the estimated incremental cost of the thermal storage pond dry cooling system, but the overall reduction is small because energy replacement is a relatively small fraction of the cost of dry cooling.

\subsection{POND CAPITAL COST}

As part of the parametric study, the effect of varying pond capital cost on the incremental power: cost of dry cooling was investigated. In Section 3 , it was shown that the pond capital cost is a function of pond location with respect to the dry cooling tower. In the base case it was assumed that the pond was located $600 \mathrm{ft}$ from the cooling tower. If site conditions and thermal effects of the pond would permit locating the pond adjacent to the cooling tower pumping plant, then it would be possible to delete the thermal storage pond pumping plant and substantially reduce the piping costs. One possible close-in pond arrangement is shown in Figure 15.

The capital cost associated with the close-in arrangement is calculated using the procedure discussed in Section 3, except that the pumping piant capital cost is deleted and the length of the supply and return piping is assumed to be $50 \mathrm{ft}$. All unit costs and overheads are the same as those used in the base case and BNW-I. (2) 
TABLE 5. Dry Cooling System Optimization for Alternate Energy Penalty Methodology for Wyodak

\begin{tabular}{|c|c|c|}
\hline Capital Cost Summary & \multirow{2}{*}{\multicolumn{2}{|c|}{$\frac{\text { Base }}{\text { cost }}$ in $\frac{\text { Variable Energy Cost }}{10^{6} \text { dollars }(1976)}$}} \\
\hline & & \\
\hline Tower & 35.7 & 35.7 \\
\hline Piping & 12.0 & 12.0 \\
\hline Condenser & 6.2 & 6.2 \\
\hline Pond & 9.9 & 9.9 \\
\hline Capacity Penalty & 8.4 & 8.4 \\
\hline Plant Scaling & 7.2 & 7.2 \\
\hline Total Capital Cost & 79.4 & 79.4 \\
\hline Unit Energy Cost Summary & \multicolumn{2}{|c|}{ Incremental energy cost in $\mathrm{mill} / \mathrm{s} / \mathrm{kWh}$} \\
\hline Total Capital Cost & 2.428 & 2.428 \\
\hline Energy Penalty & 0.121 & 0.096 \\
\hline Additional Base Plant Fuel & 0.150 & 0.150 \\
\hline \multirow[t]{2}{*}{ Operation and Maintenance } & $\underline{0.112}$ & 0.112 \\
\hline & 2.811 & 2.786 \\
\hline
\end{tabular}




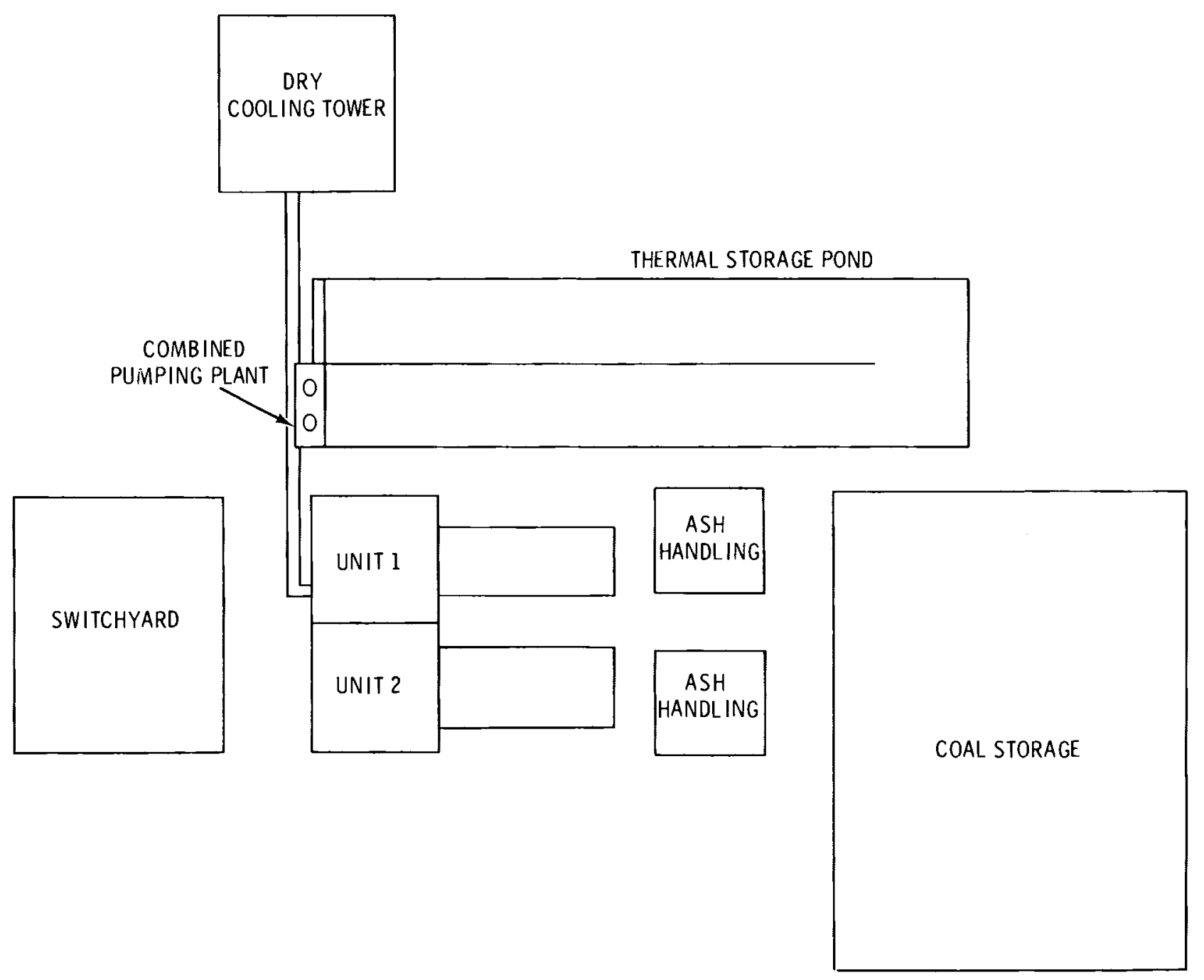

FIGURE 15. Conceptual Close-in Pond Arrangement 
Two cases were considered: the base case and the close-in pond arrangement. The close-in pond arrangement results in a substantial reduction in pond capital cost and should result in a lower incremental power cost for dry cooling. Table 6 presents the results of the simulation of both cases. As expected, the close-in pond arrangement does result in a decrease in the incremental cost of dry cooling with a thermal storage pond from 2.811 $\mathrm{mills} / \mathrm{kWh}$ to $2.664 \mathrm{mills} / \mathrm{kWh}$. While the incremental cost is decreased, the decrease is not sufficient to make the thermal storage pond system competitive with a dry cooling system without a thermal storage pond with an incremental power cost of 2.549 mills.

\subsection{CAPACITY PENALTY COST}

The method of evaluating the capacity penalty has a major impact on the incremental cost of a dry cooling system equipped with a thermal storage pond. The capacity penalty is the cost of electrical energy generating facilities necessary to provide replacement power whenever the dry-cooled power plant cannot generate its rated capacity. Because the output of the dry-cooled power plant decreases with increasing ambient temperature, the maximum deficit in power generation will occur during the hottest time period in which the plant must operate. The "hottest time period" was defined in Section 3. This section considers the effect of including the utility supply curve in the analysis of capacity penalty.

For the base case it was assumed that, whenever the power plant could not generate its rated capacity, then replacement power would be required. The replacement power was assumed to be supplied by gas turbines with sufficient capacity to meet the plant's rated output even under the worst case conditions.

A second method of analyzing the capacity penalty would be to consider the complete utility power generation system, which would include the dry-cooled plant, gas turbines and other power generation facilities. In a theoretical utility the installed generating capacity would just equal the 
TABLE 6. Dry Cooling System Optimization for Alternate Pond Location for Wyodak

\begin{tabular}{|c|c|c|}
\hline \multirow{2}{*}{ Capital Cost Summary } & \multicolumn{2}{|c|}{ Base Variable Energy Cost } \\
\hline & $\cos t i$ & in $10^{6}$ dollars $(1976)$ \\
\hline Tower & 35.7 & 35.6 \\
\hline Piping & 12.0 & 12.0 \\
\hline Condenser & 6.2 & 6.2 \\
\hline Pond & 9.9 & 5.5 \\
\hline Capacity Penalty & 8.4 & 8.5 \\
\hline Plant Scaling & 7.2 & 7.1 \\
\hline Total Capital Cost & 79.4 & 74.9 \\
\hline Unit Energy Cost Summary & Incremental & energy cost in mills $/ \mathrm{kWh}$ \\
\hline Total Capital Cost & 2.428 & 2.289 \\
\hline Energy Penalty & 0.121 & 0.122 \\
\hline Additional Base Plant Fuel & 0.150 & 0.149 \\
\hline Operation and Maintenance & $\underline{0.112}$ & $\underline{0.104}$ \\
\hline & 2.811 & 2.664 \\
\hline
\end{tabular}


peak demand and the peak demand would be supplied by the most expensive of the generating facilities. At any but peak conditions the system would have excess capacity that could be used to make up the deficit of the dry-cooled power plant. In this situation, the system would be able to supply the necessary replacement power without requiring new construction for a11 situations except peak demand period. This means that the capacity penalty should be based on the replacement power requirement only during the peak demand period (see Figures 16 and 17). Because excess system capacity exceeds loss of capacity at $t_{1}$, the capacity penalty is based on loss of capacity at $t_{2}$.

For a typical dry-cooled plant, the two approaches yield similar results because, for summer peaking utilities, the peak load occurs at approximately the same time as peak ambient temperature, which is also the time of the peak deficit in the plant's power output. One can assume that the system could not provide any replacement power and all replacement power would have to be provided by newly constructed gas turbines.

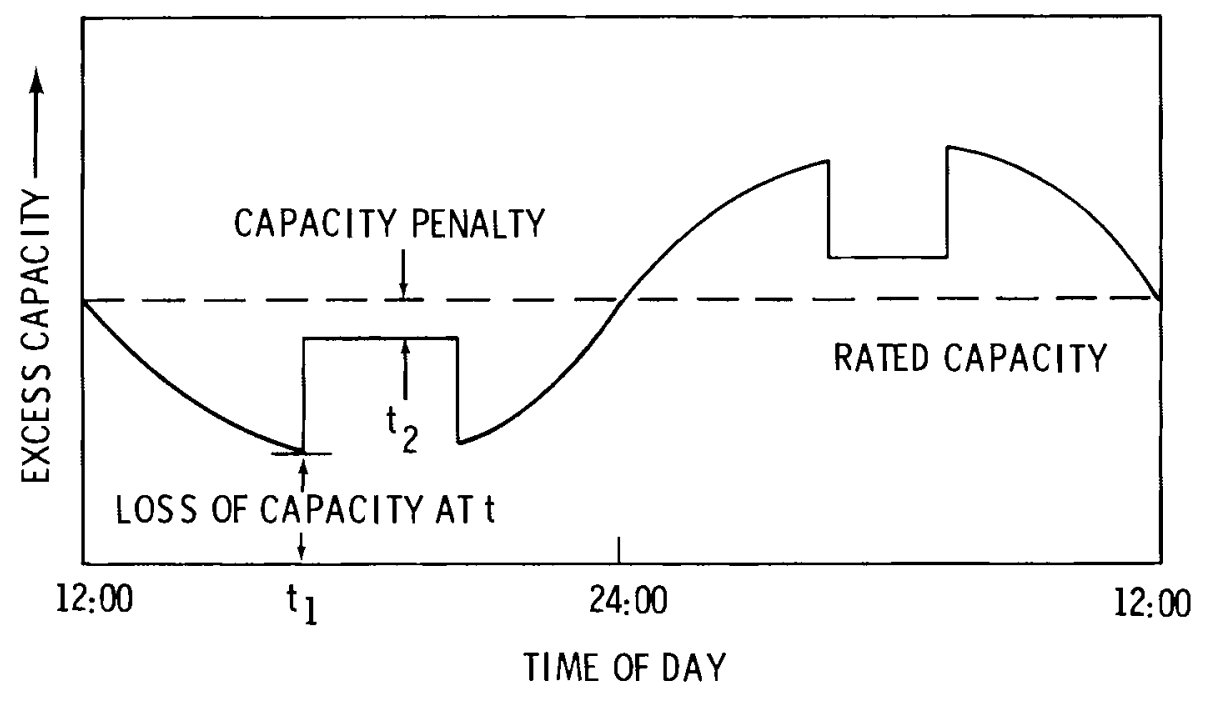

FIGURE 16. Generation Profile and Capacity Penalty 


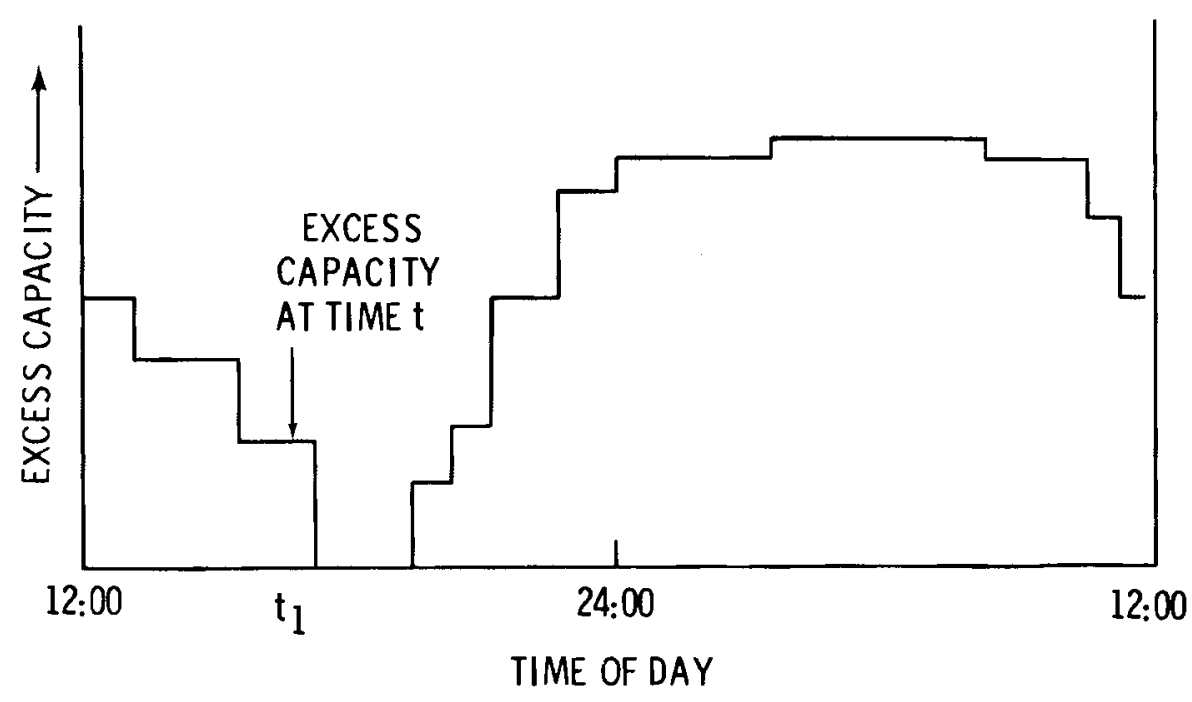

FIGURE 17. System Excess Capacity

For a dry cooling system with a thermal storage pond there may be substantial differences. With a thermal storage pond system the peak deficiency in power generation occurs just before the pond enters service. If the pond is designed so that the peak demand period always occurs during pond operation, then the maximum deficiency occurs at off-peak conditions and the system can be assumed to provide replacement power. In this case the capacity penalty is based on the difference between the rated output and the actual output with the pond in service. Because plant performance is substantially improved with the pond in service, the capacity penalty is reduced.

To investigate the impact of the method of evaluating the capacity penalty, two cases were considered: the base case and the peak demand capacity penalty method. The results are presented in Table 7 . From these results it is obvious that the method of evaluation has a major impact on the incremental cost of dry cooling. The peak demand capacity penalty method gives a substantially lower incremental cost. 
TABLE 7. Dry Cooling System Optimization for Alternate Capacity Penalty Methodology for Wyodak

Capital Cost Summary

Tower
Piping
Condenser
Pond
Capacity Penalty
Plant Scaling
Total Capital Cost
Unit Energy Cost Summary
Total Capital Cost
Energy Penalty
Additional Base Plant Fuel
Operation and Maintenance

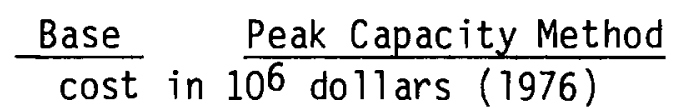

35.7

35.7

12.0

12.2

6.2

6.2

9.9

9.9

8.4

3.5

$\frac{7.2}{79.4}$

6.9

74.4

Incremental energy cost in $\mathrm{mills} / \mathrm{kWh}$
2.428
2.271
0.121
0.121
0.150
0.145
0.112
$\underline{0.112}$
2.811
2.649 
While the peak demand capacity penalty method gives substantially improved economics for the thermal storage pond concept, this method was not used as the base case for several reasons. Uncertainty exists in the shape of the electric power supply curve and in the shape and duration of the demand peak. The design of a thermal storage pond with sufficient storage capacity to insure that the peak demand period is included in the pond-in-service period would require oversizing the pond to a possibly nonoptimal size. The costs associated with oversizing the pond were not included in the analysis presented in Table 7.

For dry cooling to contribute substantially to conserving national water resources it must be viewed as a base load technique that would be used on a large scale. While a utility system may currently have excess capacity at off-peak conditions, sufficient to provide reserve for a dry-cooled plant, an increased use of dry cooling with thermal storage ponds would tend to el iminate this reserve, requiring the construction of additional generating facilities. While the peak demand capacity penalty method may be reasonable for the first plant equipped with a thermal storage pond, additional plants with thermal storage ponds may require additional capacity above that predicted by the peak demand capacity penalty method. For a specific utility with sufficient excess capacity at off-peak conditions, the peak demand capacity penalty method may be justified. However, for a general analys is of the thermal storage pond concept, the more conservative approach of viewing the plant as an isolated facility consisting of the plant and a gas turbine required at all times to provide the noted capacity was felt to be more satisfactory.

\subsection{DESIGN TEMPERATURE}

The design temperature of the dry cooling system is the ambient temperature at which the plant will generate its rated output. A high design temperature results in reduced replacement energy costs and capacity penalty but the capital cost of the dry cooling system is increased. A low design temperature results in reduced capital costs but the energy and capacity 
penalties are increased. The optimization of dry cooling systems without thermal storage ponds using BNW-I has shown that the optimal design temperature is around $50^{\circ} \mathrm{F}$. This was used as the base case design temperature for the thermal storage pond optimization.

To investigate the impact of varying design temperature, two additional design temperatures were considered: $30^{\circ} \mathrm{F}$ and $70^{\circ} \mathrm{F}$. An optimized plant and related incremental cost were determined for a dry cooling system, both with and without a thermal storage pond. The results are presented in Tables 8 and 9. It appears that the $50^{\circ} \mathrm{F}$ design temperature is near optimum for the dry cooling system equipped with a thermal storage pond. In addition, the variation in design point temperature does not appear to increase the economic viability of the thermal storage pond system. At a design temperature of both $30^{\circ} \mathrm{F}$ and $70^{\circ} \mathrm{F}$ the incremental cost of dry cooling with a thermal storage pond is substantially higher for the dry cooling without a thermal storage pond.

\subsection{METEOROLOGY}

When considering the economic viability of the thermal storage pond concept, the trade-off between the increased capital cost of the pond and the resulting reduction in lost capacity during the hottest part of the day is of concern. The reduction in lost capacity is a function of ambient conditions with the thermal pond concept providing the greatest benefit in hot climates with large daily temperature variations; therefore, the economic attractiveness of the thermal pond concept is dependent on site meteorology.

The meteorology of a particular site is characterized by a maximum temperature and a distribution of temperatures on a yearly average basis. Two sites were considered for this study: Wyodak and Phoenix. Wyodak was selected as the base case to allow comparison with previous results. Phoenix was selected as a typical site that would be favorable for the thermal storage pond concepts. The cumulative temperature curves for these sites are shown in Figure 18. The cumulative temperature profile for Wyodak has been adjusted so that the cumulative hours below $30^{\circ} \mathrm{F}$ are included in the cumulative hours at $30^{\circ} \mathrm{F}$. This in no way affects the cooling tower design or performance. 
TABLE 8. Dry Cooling System Optimization for A Design Temperature of $30^{\circ} \mathrm{F}$ for Wyodak

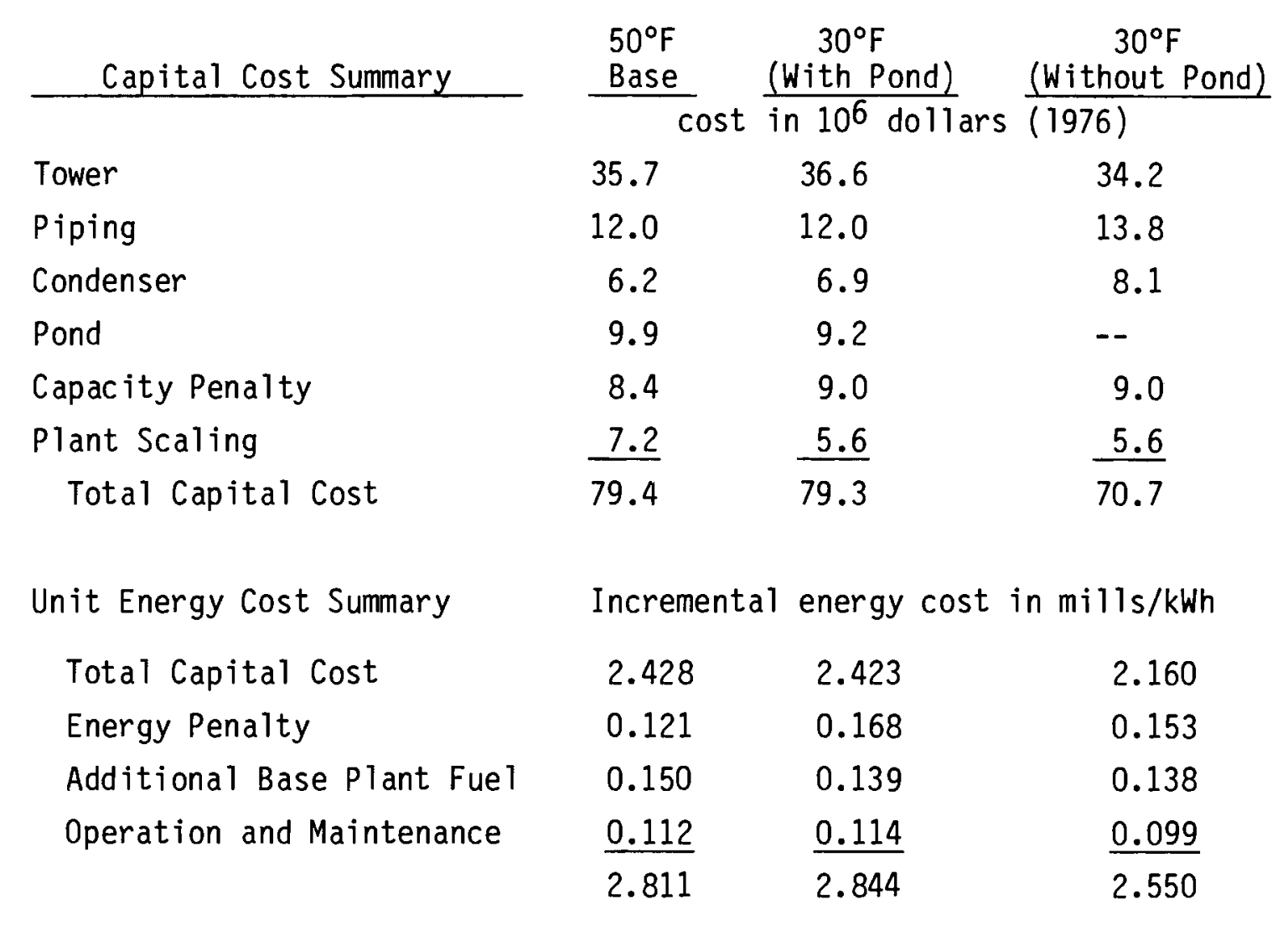


TABLE 9. Dry Cooling System Optimization for A Design Temperature of $70^{\circ} \mathrm{F}$ for Wyodak

\begin{tabular}{|c|c|c|c|}
\hline Capital Cost Summary & $\begin{array}{l}50^{\circ} \mathrm{F} \\
\text { Base }\end{array}$ & $\begin{array}{c}70^{\circ} \mathrm{F} \\
\text { (With Pond) } \\
\end{array}$ & $\begin{array}{l}70^{\circ} \mathrm{F} \\
\text { (Without Pond) }\end{array}$ \\
\hline & \multicolumn{3}{|c|}{ cost in $10^{6}$ dollars (1976) } \\
\hline Tower & 35.7 & 38.5 & 39.2 \\
\hline Piping & 12.0 & 12.9 & 13.7 \\
\hline Condenser & 6.2 & 5.9 & 6.1 \\
\hline Pond & 9.9 & 9.8 & -- \\
\hline Capacity Penalty & 8.4 & 6.4 & 6.9 \\
\hline Plant Scaling & 7.2 & 14.1 & $\underline{13.2}$ \\
\hline Total Capital Cost & 79.4 & 87.6 & 79.1 \\
\hline Unit Energy Cost Summary & \multicolumn{3}{|c|}{ Incremental energy cost in $\mathrm{mills} / \mathrm{kWh}$} \\
\hline Total Capital Cost & 2.428 & 2.676 & 2.416 \\
\hline Energy Penalty & 0.121 & 0.036 & 0.043 \\
\hline Additional Base Plant Fuel & 0.150 & 0.178 & 0.163 \\
\hline \multirow[t]{2}{*}{ Operation and Maintenance } & $\underline{0.112}$ & $\underline{0.118}$ & $\underline{0.103}$ \\
\hline & 2.811 & 3.008 & 2.735 \\
\hline
\end{tabular}




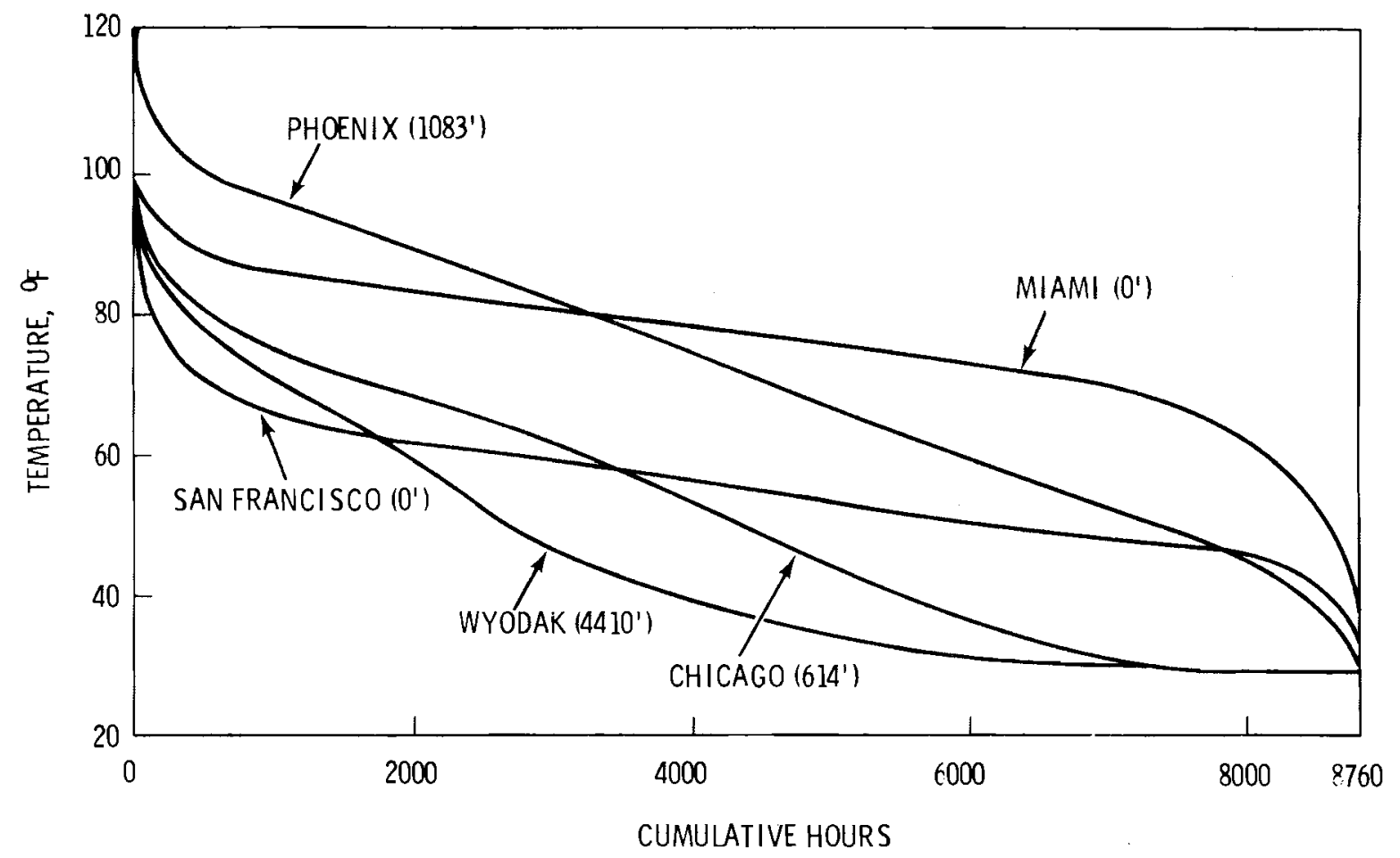

FIGURE 18. Cumulative Temperature Distribution Taken from Ten-Year Average for Five Site Meteorologies (Site Elevation in Parentheses)

As discussed in Section 3, the simulation of a dry cooling system equipped with a thermal storage pond requires that two cumulative temperature curves be used, one for the "pond out of service" mode and one for the "pond in service" mode. The Wyodak curves are based on a detailed analysis of 1974 weather data. Time did not allow such a detailed analysis of the Phoenix weather data. The cumulative temperature curve for the "pond in service" mode for Phoenix was developed by assuming a daily temperature variation of $30^{\circ}$, typical of the region. Once a peak hour was identified, the next low temperature period would then have a temperature $30^{\circ}$ below the peak hour temperature. In identifying peak hours, it was assumed that all hours above $110^{\circ} \mathrm{F}$ were peak hours and half of the hours between $90^{\circ} \mathrm{F}$ and $110^{\circ} \mathrm{F}$ were peak hours. 
Meteorology influences the design and cost of the dry cooling system in three ways. The maximum ambient air temperature partly determines the maximum initial temperature difference (ITD) of the heat exchanger and the capital cost of the gas turbines required to make up lost performance. The distribution of temperature over the year also determines the cost of fuel for the gas turbine. The thermal storage pond decreases the lost performance and lost energy. This results in the optimization process selecting a smaller cooling system.

The results of the parametric study are presented in Table 10. Both cases were modeled assuming a modified conventional turbine. In addition, a dry cooling system without a thermal storage pond was modeled using Phoenix weather data and the results are presented in Table 10. From these results it is obvious that the incremental cost of dry cooling with a thermal storage pond does increase when comparing a hot climate such as Phoenix and a cooler climate such as Wyodak. The significant result is that the cost of dry cooling without a thermal storage pond rises more rapidly, so that for a climate like Phoenix the thermal storage pond decreases the incremental cost of dry cooling.

To consider the maximum potential savings resulting from the thermal storage pond concept an additional case was investigated. It was assumed that a site suitable for a reduced capital cost "close-in" pond was available in the Phoenix area. Table 11 presents the results of the optimization. In this case, the thermal storage pond has substantially reduced the incremental cost of dry cooling from 4.306 to $3.505 \mathrm{mi} 1 \mathrm{~s} / \mathrm{kWh}$ for a $19 \%$ reduction.

The three turbine types were considered for the Phoenix meteorology. The results of the optimization are presented in Tables 12 and 13. It appears that the high back pressure turbine is optimal for the Phoenix meteorology. This coincides with the results of the previous study. ${ }^{(2)}$

When considering the results for Phoenix meteorology it should be remembered that the temperature profiles for the pond in service are based on the assumptions given above. Before a firm statement on the incremental cost of dry cooling with Phoenix meteorology can be made, a detailed evaluation of the local meteorology must be completed. 
TABLE 10. Dry Cooling System Optimization for Phoenix Meteorology

\begin{tabular}{|c|c|c|c|}
\hline Capital Cost Summary & Base & $\begin{array}{c}\text { Phoenix } \\
\text { (With Pond) }\end{array}$ & $\begin{array}{l}\text { Phoen ix } \\
\text { (Without Pond) }\end{array}$ \\
\hline & \multicolumn{3}{|c|}{ cost in $10^{6}$ dollars $(1976)$} \\
\hline Tower & 35.7 & 40.0 & 39.8 \\
\hline Piping & 12.0 & 17.7 & 27.8 \\
\hline Condenser & 6.2 & 8.6 & 10.0 \\
\hline Pond & 9.9 & 15.0 & -- \\
\hline Capacity Penalty & 8.4 & 8.8 & 9.2 \\
\hline Plant Scaling & 7.2 & 7.4 & 14.0 \\
\hline Total Capital Cost & 79.4 & 97.5 & 120.8 \\
\hline Unit Energy Cost Summary & \multicolumn{3}{|c|}{ Incremental energy cost in mills/kWh } \\
\hline Total Capital Cost & 2.428 & 2.979 & 3.687 \\
\hline Energy Penalty & 0.121 & 0.375 & 0.177 \\
\hline Additional Base Plant Fuel & 0.150 & 0.165 & 0.271 \\
\hline \multirow[t]{2}{*}{ Operation and Maintenance } & $\underline{0.112}$ & $\underline{0.143}$ & $\underline{0.171}$ \\
\hline & $\overline{2.811}$ & $\overline{3.662}$ & $\overline{4.306}$ \\
\hline
\end{tabular}


TABLE 11. Dry Cooling System Optimization for Phoenix Meteorology and Close-in Pond Location

\begin{tabular}{|c|c|c|}
\hline Capital Cost Summary & \multirow{2}{*}{\multicolumn{2}{|c|}{$\begin{aligned} & \text { Phoenix with } \begin{array}{l}\text { Phoenix } \\
\text { cost in } 10^{6}\end{array} \\
& \text { Close-in Pond } \\
& \text { dollars (1976) }\end{aligned}$}} \\
\hline & & \\
\hline Tower & 40.0 & 39.8 \\
\hline Piping & 17.7 & 18.5 \\
\hline Condenser & 8.6 & 8.6 \\
\hline Pond & 15.0 & 8.9 \\
\hline Capacity Penalty & 8.8 & 8.8 \\
\hline Plant Scaling & 7.4 & 7.8 \\
\hline Total Capital Cost & 97.5 & 92.4 \\
\hline Unit Energy Cost Summary & \multicolumn{2}{|c|}{$\begin{array}{c}\text { Incremental energy cost } \\
\text { in } \mathrm{mill} / \mathrm{s} / \mathrm{kWh}\end{array}$} \\
\hline Total Capital Cost & 2.979 & 2.823 \\
\hline Energy Penalty & 0.375 & 0.377 \\
\hline Additional Base Plant Fuel & 0.165 & 0.172 \\
\hline \multirow[t]{2}{*}{ Operation and Maintenance } & $\underline{0.143}$ & $\underline{0.133}$ \\
\hline & 3.662 & 3.505 \\
\hline
\end{tabular}


TABLE 12. Dry Cooling System Optimization for Phoenix Meteorology and No Thermal Storage Pond with Various Turbine Designs

\begin{tabular}{|c|c|c|}
\hline Capital Cost Summary & $\begin{array}{c}\text { Modified } \\
\text { Conventional } \\
\end{array}$ & $\begin{array}{l}\text { High Back } \\
\text { Pressure }\end{array}$ \\
\hline & \multicolumn{2}{|c|}{ cost in $10^{6}$ dollars (1976) } \\
\hline Tower & 59.8 & 35.2 \\
\hline Piping & 27.8 & 14.7 \\
\hline Condenser & 10.0 & 7.5 \\
\hline Pond & -- & -- \\
\hline Capacity Penalty & 9.2 & 9.1 \\
\hline Plant Scaling & 14.0 & $\underline{13.4}$ \\
\hline Total Capital Cost & 120.8 & 78.9 \\
\hline Unit Energy Cost Summary & \multicolumn{2}{|c|}{$\begin{array}{c}\text { Incremental energy cost } \\
\text { in mills } / \mathrm{kWh}\end{array}$} \\
\hline Total Capital Cost & 3.687 & 2.408 \\
\hline Energy Penalty & 0.177 & 0.127 \\
\hline Additional Base Plant Fuel & 0.271 & 0.542 \\
\hline \multirow[t]{2}{*}{ Operation and Maintenance } & $\underline{0.171}$ & $\underline{0.099}$ \\
\hline & 4.306 & 3.176 \\
\hline
\end{tabular}


TABLE 13. Dry Cooling System Optimization for Phoenix Meteorology and Thermal Storage Pond with Various Turbine Designs

Capital Cost Summary

Tower

Piping

Condenser

Pond

Capacity Penalty

Plant Scaling

Total Capital Cost

Unit Energy Cost Summary

Total Capital Cost

Energy Penalty

Additional Base Plant Fue 1

Operation and Maintenance
Modified High Back $\frac{\text { Conventional }}{\text { cost in } 10^{6}}$ dollars (1976)

40.0

30.3

17.7

10.1

8.6

5.8

15.0

9.1

8.8

7.6

7.4

11.3

97.5

74.2

Incremental energy cost in $\mathrm{mi} 11 \mathrm{~s} / \mathrm{kWh}$
2.979
2.268
0.375
0.261
0.165
0.510
$\underline{0.143}$
$\underline{0.097}$
3.662
3.136 


\subsection{CONCLUSIONS}

Five major conclusions drawn from this study are:

1. The thermal storage pond concept reduces the incremental cost of dry cooling by $15 \%$ for a site with meteorology similar to Phoenix, Arizona, if the system uses a modified-conventional turbine. No reduction in cost was experienced for a more moderate site, such as Wyodak, Wyoming, or if a high back pressure turbine is used.

2. The optimal turbine type (high back pressure) and optimal design temperature $\left(50^{\circ} \mathrm{F}\right)$ are the same for all cases.

3. The results are insensitive to variations in the method of evaluating replacement energy cost.

4. The results are sensitive to site meteorology and the method of evaluating capacity penalty.

5. The pond should be built as close as feasible to the dry cooling tower, although the incremental cost of dry cooling is not a strong function of this variable.

In addition, the flexibility of the BNW-I optimization code has been increased by the addition of algorithms for the analysis of thermal storage ponds. The code can now be used to analyze site-spec if ic proposals.

Before the thermal storage pond can be considered an economically viable concept for plant sites with moderate or cool meteorology, ways to reduce the projected cost must be found.

The economics of thermal storage ponds may be more favorable in certain situations not considered in this report, such as:

a) auxiliary uses of the pond, e.g., for makeup or emergency water storage, and

b) the use of a thermal storage pond with a dry cooling system for a solar thermal power plant. Such a plant would particularly benefit from the capacitive effects of the thermal storage pond because of the diurnal variation in the rate of power production and heat rejection. 


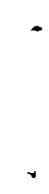




\section{REFERENCES}

1. E. C. Guyer, An Engineering and Economic Evaluation of Some Mixed-Mode Waste Heat Rejection Systems. Ph.D thesis, Massachusetts Institute of Technology, Cambridge, MA, 1976.

2. B. C. Fryer, D. J. Braun, D. J. Braun, L. E. Wiles and D. W. Faletti, An Engineering and Cost Comparison of Three Different All-Dry Cooling Systems. BNWL-2121, Battelle, Pac if ic Northwest Laboratories, Richland, WA 99352, September 1976.

3. D. J. Braun, D. J. Braun, L. E. Wiles, W. V. DeMier and D. W. Faletti, $\underline{A}$ User's Manual for the BNW-I Optimization Code for Dry-Cooled Power Plants, Volume I. BNWL-2180, VoT. I, BattelTe, Pacific Northwest Laboratories, Richland, WA 99352, January 1977.

4. D. J. Braun, D. J. Braun, L. E. Wiles, W. V. DeMier and D. W. Faletti, $\underline{A}$ User's Manual for the BNW-I Optimization Code for Dry-Cooled Power Plants, Volume II. BNWL-2180, Vol. II, Battelle, Pacific Northwest Laboratories, Richland, WA 99352, January 1977.

5. P. A. Ard, C. H. Henager, D. R. Pratt and L. E. Wiles, Costs and Cost Algorithms for Dry Cooling Tower Systems. BNWL-2123, Battelle, Pacific Northwest Laboratories, Richland, WA 99352, September 1976. 


\section{$\underline{\text { DISTRIBUTION }}$}

No. of

Copies

\section{OFFSITE}

\section{U.S. Department of Energy \\ A. A. Churm \\ Chicago Patent Group \\ 9800 South Cass Avenue \\ Argonne, IL 60439 \\ U.S. Department of Energy \\ Office of Assistant General \\ Counsel for Patents \\ Washington, DC 20545}

\section{DOE Technical Information Center}

10 U.S. Department of Energy

I. Helms

Division of Advanced Systems and

Materials Production

Washington, DC 20545

U.S. Department of Energy

W. F. Savage

Division of Advanced Systems and

Materials Production

Washington, DC 20545

U.S. Department of Energy

N. Goldenberg

Director, Division of Advanced

Systems and Materials Production

Washington, DC 20545

U.S. Department of Energy

C. Grua

Environmental Control Technology

Office of Environmental

Compliance Overview

Washington, DC 20545
No. of

Copies

U.S. Department of Energy

W. E. Mott

Director, Environmental Control Technology

Office of Environmental

Compliance Overview

Washington, DC 20545

U.S. Department of Energy

J. M. Deutch

Director, Office of Energy

Research

Washington, DC 20545

Allied Chemical Company

B. R. Dickey

550 2nd Street

Idaho Falls, ID 83401

Allis-Chalmers Power Systems, Inc. J. S. Joyce

1135 South 70th Street

West Allis, WI 53214

Aluminum Company of America

E. T. Wanderer

Alcoa Technical Center

Alcoa Center, PA 15069

American Electric Power Service Corporation

H. J. Janzon

2 Broadway

New York, NY 10004

American Electric Power Service Corporation

C. Swenson

2 Broadway

New York, NY 10004

Aqua-Chem

R. M. Ahlgren

P.0. Box 421

Milwaukee, WI 53201 
No. of

Copies

Arizona Public Service Co.

W. E. Campbel1

P.0. Box 21666

Phoenix, AZ 85036

Arizona Public Service Co. T. Woods

2121 W. Cheryl Drive

Phoen ix, AZ 85021

Babcock \& Wilcox

M. W. Peterson

Fossil Power Division

20 South Van Buren

Barberton, $\mathrm{OH} 44203$

Baltimore Aircoil Co., Inc.

E. Schinner

P.0. Box 7322

Baltimore, MD 21227

Baltimore Gas \& Electric Co.

G. C. Creel

Gas \& Electric Building

Baltimore, MD 21203

Battelle-Geneva

J. P. Budliger

7 Route De Drizi

1227 Geneva, SWITZERLAND

Bechtel Corporation

$P$. Leung

P.0. Box 60860

Terminal Annex

Los Angeles, CA 90060

Bechtel Corporation

G. R. Ret $i$

P.0. Box 3965

San Francisco, CA 94119

R. W. Beck and Associates

J. P. Rossie

400 Prudential Plaza

Denver, CO 80202
No. of

Copies

Betz Environmental Engineers

J. Soost

One Plymouth Meeting Mall

Plymouth Meeting, PA 19462

Black, Crow and Eidsness, Inc.

C. G. Thompson

807 South McDonough

Montogomery, AL 35104

Black Hills Power and Light Company

B. Westre

P.0. Box 1400

Rapid City, SD 57701

Boeing Aerospace Division

D. Gilbert (M.S. 2ROO)

P.0. Box 3999

Seattle, WA 98124

Bonneville Power Administration

E. H. Hall

1002 N.E. Holladay Street

Box 3621

Portland, OR 97208

Burns and Roe, Inc. 700 Kinder Kamack Rd.

Orade 1, NY 07649

Cal ifornia Energy Commission

C. Webb

1111 Howe Avenue

Sacramento, CA 95825

California State Energy Resources Conservation and Development Commiss ion

L. E. Stamets

1111 Howe Avenue

Sacramento, CA 95825

Carolina Power \& Light Co. J. Sell

336 Fayettesville Street

Raleigh, NC 27602 
No. of

Copies

Catalytic Construction Corp.

J. Morse

P.0. Box 15232

Charlotte, NC 28210

Ceramic Cooling Tower Co.

P. A. Frohwerk

P.0. Box 425

Fort Worth, TX 76101

Chicago Bridge and Iron Company

C. T. Bouchard

Route 59

Plainfield, IL 60544

Combustion Engineering Lummus Engineering Company

R. J. Croke

1515 Broad St

Bloomingfield, NJ 07003

Columbus and Southern Ohio Electric Co.

L. W. Meridith

General Manager, Generation Department

215 North Front Street

Columbus, $\mathrm{OH} 43215$

Combustion Engineering

H. H. Osborn

Air Preheater Company

Wellsville, NY 14895

Commonwealth Edison

R. H. Holyoak

One First Plaza

P.0. Box 767

Chicago, IL 60690

Consolidated Edison Co. of New York, Inc.

W. A. Messner

4 Irving Place

New York, NY 10003
No. of

Copies

Consolidated Edison Co. of New York, Inc.

C. L. Newman

4 Irving Place

New York, NY 10003

Cooling System, Inc.

C. Mitche 1

8490 Avenue 296

Visalia, CA 93877

Cornell University

F. K. Moore

Ithaca, NY 14850

Curtiss-Wright Corporation

R. J. Haberski

One Passaic Street

Wood Ridge, NJ 07075

Dames \& Moore

L. Craton

Suite 1000

1100 Glendon Avenue

Los Angeles, CA 90024

Dames \& Moore

P. Gottlieb

Suite 1000

1100 Glendon Avenue

Los Angeles, CA 90024

Delmarva Power \& Light

F. Cook

800 King Street

Wilmington, DE 19801

Dow Chemical Company

E. Wagener

2800 Mitche11 Drive

Walnut Creek, CA 94598

Duke Power Company

S. K. Blackley

P.0. Box 2178

Charlotte, NC 28201 
No of

Copies

Duquesne Light Co.

J. Latshaw

435 6th Avenue

Pittsburgh, PA 15219

Dynatech Company

E. Guyer

99 Erie Street

Cambridge, MA 02139

Ecodyne

J. Slotnik

607 First Street, S.W.

Massillon, $\mathrm{OH} 44646$

Ecodyne Cooling Products Co.

J. K. Swindt

P.0. Box 1267

Santa Rosa, CA 95403

Ecodyne Cooling Products

K. D. Whitehead

P.0. Box 1267

Santa Rosa, CA 95403

Electric Power Research Institute

J. Maulbetsch

3412 Hilview Avenue

P.0. Box 10412

Palo Alto, CA 94304

Empire State Electric Energy Research Corp.

L. Geller

1271 Avenue of the Americas

New York, NY 10020

Environmental Protection Agency

T. G. Brna (MD-61)

IERL/RTP

Research Triangle Park, NC 27711

Environmental Protection Agency

A. Galley (WH-552)

401 M. Street SW

Washington, DC 20460
No of

Copies

Environmental Protection Agency

M. Maxwell (MD-61)

IERL/RTP

Research Triangle Park, NC 27711

Environmental Protection Agency

F. H. Rainwater

Pacific Northwest Water Laboratory

200 S.W. 35th Street

Corvallis, OR 97330

Environmental Protection Agency

F. A. Roberts

200 S.W. 35th Street

Corvallis, OR 97330

Environmental Sciences and Services

W. G. Hoydysh

150 East 73rd Street

New York, NY 10021

Environmental Systems Corporation

K. Wilber

P.0. Box 2525

Knoxville, TN 37901

ERG Incorporated

G. M. Benson

Lowe 11 57th Street

Oakland, CA 94608

Exxon Research Center

J. G. Stevens

Bldg. 1, Rm. 2048

P.0. Box 8

Linden, NJ 07036

Federal Power Commission

E. Sligh

825 N. Capitol Street

Washington, DC 20426

Florida Power \& Light Co.

C. Henderson

9250 W. Flagler Street

Miami, FL 33174 
No. of

Copies

Foster Wheeler Development Corporation

R. J. Zoschak

Technical Director, Applied

Thermodynamics Research

12 Peach Tree Hill Road

Livingston, NJ 07039

Foster Wheeler Energy Corporation

E. L. Damon

110 S. Orange Avenue

Livingston, NJ 07039

Foster Wheeler Energy Corporation

W. H. Fisher, Jr.

Project Manager

110 S. Orange Avenue

Livingston, NJ 07039

Foundation Sciences, Inc.

L. E. Wilkinson

Cascade Building

Portland, OR 97204

Franklin Institute

A. M. Rub in

Twentieth \& Parkway

Philadelphia, PA 19103

Frick Company

J. Bibroff

15302 El Mar Lane

Kerman, CA 93630

GEA Airexchangers, Inc.

B. Davis

P.0. Box 1377

Thomasville, GA 31792

General Atomic Company

A. C. Eulberg

P.0. Box 81608

San Diego, CA 92138
No. of

Copies

General Electric Co.

E. H. Miller

Large Steam Turbine Division

300 Nott Street

Schenectady, NY 12301

General Motors Corp.

R. K. Shah

Harrison Radiator Division

Lockport, NY 14094

Georgia Power Co.

T. E. Byer ley

P.0. Box 4545

Atlanta, GA 30302

Gilbert Associates, Inc.

J. F. Sebald

525 Lancaster Avenue

Reading, PA 19603

Heat Transfer Research Inc.

J. E. Taborek

$1000 \mathrm{~S}$. Fremont Avenue

Alhambra, CA 91802

Hudson Products

M. W. Larinoff

6855 Horwin Drive

Houston, TX 77036

Hudson Products

E. C. Smith

6855 Horwin Drive

P.0. Box 36100

Houston, TX 77036

H2M Corporation

H. D. Freudenthal

500 Broad Hollow Road

Melville, NY 11746

Inger so 11-R and

W. R. Scott, Jr.

Phillipsburg, NJ 08865 
No. of

Copies

Italimpiant $i-S o c i e t a$ Italiana Impianti p.a.

C. Rocco

Piazza, Piccapietra 9

18121 Genoe, ITALY

Los Alamos Scientific Laboratory D. Abbey

S-2, MS 606

Los Alamos, NM 87545

Los Angeles Department of Water and Power

J. L. Mulloy

111 N. Hope Street

Los Angeles, CA 90012

Louisiana Power \& Light Co.

D. L. Aswe 11

142 Delaronde Street

New Or leans, LA 70174

The Charles T. Main Co.

E. S. Miliaras

Southeast Tower

Prudential Center

Boston, MA 02199

Marley

C. A. Baird

12 S. 12th Street

Philadelphia, PA 19107

Mar ley

J. D. Holmberg

5800 Fox Ridge Drive

Mission, KS 66202

Marley

R. Landon

5800 Fox Ridge Drive

Mission, KS 66202

Martin Marietta Laboratories

$L$. Bongers

1450 South Rolling Road

Baltimore, MD 21227
No. of

Copies

Masachusetts Institute of Technology

L. R. Glicksman

77 Massachusetts Avenue

Cambridge, MA 02139

Massachusetts Institute of Technology

M. W. Golay

77 Massachusetts Avenue

Cambridge, MA 02139

Masachusetts Institute of Techno logy

R. Har leman

Department of Civil Engineering

77 Massachusetts Avenue

Cambridge, MA 02139

McDonnel1 Douglas Astronautics Company

W. H. P. Drummond

5301 Balsa Avenue

Huntington Beach, CA 92647

McDonne 11 Douglas Astronautics Company

S. O'Hare

5301 Balsa Avenue

Huntington Beach, CA 92647

Minnesota Power Cooperative, Inc. L. A. Hillier

Box 1318

Grand Forks, ND 58201

Montana Power Co.

$R$. Hof acher

40 E. Broadway

Butte, MT 59701

Niagara Blower

W. Kals

405 Lexington Avenue

New York, NY 10017 
No. of

Copies

Northeast Utilities

R. H. Meyer

P.0. Box 270

Hartford, CT 06101

Northern States Power Co.

R. Stansfield

414 Nicollet Mal1

Minneapolis, MN 55401

N.U.S. Corporation

S. Lefton

2 Palo Alto Square (Suite 624)

Palo Alto, CA 94304

Oak Ridge National Laboratory

J. W. Miche 1

OTEC Heat Exchange Project

Activity

Box $Y$

Oak Ridge, TN 37830

Orange \& Rockland Utilities, Inc.

R. H. Metzger

Environmental Services Manager

75 West Route 59

Spring Valley, NJ 10977

Oregon State University

L. P. Davis

Department of Mechanical

Engineering

Corvallis, OR 97330

Oregon State University

C. E. Wicks

Department of Chemical Engineering

Corvallis, OR 97330

Oregon State University

J. G. Knudson

Engineering Experiment Station

Corvallis, OR 97330
No. of

Copies

Pacific Gas \& Electric

A. A. Ariey

77 Beale Street

San Francisco, CA 94106

Pacific Gas \& Electric

F. F. Mautz

77 Beale Street

San Francisco, CA 94106

Pacific Power \& Light Co.

W. C. Bruaer

Public Service Bldg.

Portland, OR 97204

Pennsylvania Power \& Light

W. Dussinger

2 North Ninth Street

Allentown, PA 18101

Pennsylvania Power \& Light

D. G. Pfeiffer

2 North Ninth Street

Allentown, PA 18101

PFR Engineering Systems, Inc.

T. Rozenmann, President

Suite 832

4676 Admiralty Way

Marina del Rey, CA 90291

Philadelphia Electric Co.

J. Allen

2301 Market Street

Philadelphia, PA 19101

Philadelphia Electric Co.

S. J. Kowalski

2301 Market Street, NZ-1

Philadelphia, PA 19101

Philadelphia Electric Co. J. B. Machel

2301 Market Street, NZ-1

Philadelphia, PA 19101 
No. of

Copies

Philadelphia Electric Co.

D. Marano

2301 Market Street, NZ-1

Philadelphia, PA 19101

Prof. Ing. Car lo Roma

Piazza delle Muse 8

Rome, ITALY

Pickard Low \& Garrick

L. Rust

120018 th St. NW

Suite 612

Washington, DC 20036

Power Generation Cooling Systems

G. L. Henderson

4714-52nd Street S.

Seattle, WA 98118

Public Service of Colorado

R. F. Walker

5900 E. 39th Avenue

Denver, CO 80207

Public Service Company of Indiana

S. W. Shields

$V$. P. Engineering

100 East Main Street

Plainfield, IN 46168

Public Service Company of New Mexico

C. D. Bedford

P.0. Box 2267

Albuquerque, NM 87103

Public Service Company of New Mexico

J. D. Maddox

Corporate Planning Dept.

Albuquerque, NM 87103

Quirk, Lawler and Mattusky, Eng.

J. Lawler

5055 th Avenue

New York, NY 10017
No. of

Copies

Radian Corporation

F. B. Mesich

P.0. Box 9948

Austin, TX 78766

Research Cottrell

G. E. Collins

Hamon Cooling Tower Division

Box 750

Bound Brook, NJ 08805

Research Cottre11

R. H. Hannon

Hamon Cooling Tower Division

Box 750

Bound Brook, NJ 08805

Resources Conservation Company

H. Herrigel

P.0. Box 936

Renton, WA 98055

Reynolds Aluminum Co.

R. Lindberg

Reynolds Metallurgical Research Laboratory

Richmond, VA 23261

Richmond Field Station

H. H. Sephton

47th and Hoffman Blvd.

Richmond, CA 94804

San Diego Gas \& Electric

R. G. Lacy

101 Ash Street

San Diego, CA 92107

Seatt le City Light

T. R. Miller

Principal Mechanical Engineer

1015 Third Avenue

Seattle, WA 98104 
No. of

Copies

Seattle City Light

R. G. Sheehan

1015 Third Avenue

Seattle, WA 98104

Southern California Edison

R. S. Currie

2244 Walnut Grove Avenue

Rosemead, CA 91770

Southern California Edison

W. C. Martin

2244 Walnut Grove Avenue

Rosemead, CA 91770

Southern California Edison

F. A. McCracken

2244 Walnut Grove Avenue

Rosemead, CA 91770

Southern Services, Inc.

C. H. Goodman

P.0. Box 2625

Birmingham, AL 35202

Stanford University

A. L. London

Department of Mechanical

Engineering

Stanford, CA 94305

Stearns-Rogers, Inc.

J. Y. Parce

Box 5888

Denver, CO 80217

Stewart-Warner Corporation

South Wind Division

V. N. Tramontini

1514 Dover Street

Indianapolis, IN 46221

Stone \& Webster Engineering Corp.

D. H. Guild

225 Franklin Street

Boston, MA 02107
No. of

Copies

Tampa Electric Co.

H. I. Wilson

P.0. Box 111

Tampa, FL 33601

Tennessee Valley Authority

Energy Research

R. D. Boroughs

1345 Commerce Union Bank Building

Chattanooga, TN 37401

Tennessee Valley Authority

H. B. Flora, III

1320 Commerce Union Bank Building

Chattanooga, TN 37401

Texas Electric Service Co.

W. Keel

115 W. Seventh Street

Fort Worth, TX 76102

Tucson Gas \& Electric

A. A. Ward

220 W. 6 th Street

Tucson, AZ 85701

Union Carbide Corp.

J. A. Bartz

Linde Division

61 East Park Drive

Tonawanda, NY 14150

Union Carbide Corp.

G. J. Kidd

ORGDP - K-25

P.0. Box P, Mail Stop 197

Oak Ridge, TN 37803

Union Carbide Corp.

$F$. Notaro

Linde Division

61 East Park Drive

Tonawanda, NY 14150 
United Engineers \& Constructors

G. A. Englesson

30 S. 17 th Street

Philadelphia, PA 19103

United Engineers \& Constructors

M. $\mathrm{Hu}$

30 S. 17th Street

Philadelphia, PA 19103

University of Bremen

K. Simhan

Bremen, WEST GERMANY

University of Iowa

J. F. Kennedy

Hydraulic Research Institute

Iowa City, IA 52240

University of Kentucky

T. E. Eaton

Mechanical Engineering Department

Lexington, KY 40506

U.S. Congress

G. Haimes

214 Massachusetts Avenue NE

Washington, DC 20510

U.S. Fish and Wildlife Service

B. L. Foder

Information Transfer Specialist

National Power Plant Team

1451 Green Road

Ann Arbor, MI 48105

United States Steel Corp.

T. L. Myron

Research Laboratory

Monroeville, PA 15146

Utah Power \& Light

M. W. Russon

1407 W. N. Temple

Salt Lake City, UT 84103
Vermont Yankee Nuclear Power

E. Gaines, Jr.

77 Grove Street

Rutland, VT 05701

Virginia Electric \& Power Co. S. Ragone

700 E. Franklin Street

Richmond, VA 23261

Washington Public Power Supply System

J. Chasse

P.0. Box 968

300 George Washington Way

Richland, WA 99352

Washington State University

R. W. Crain, Jr.

Department of Mechanical

Engineering

Pullman, WA 99164

Washington Water Power Co.

D. L. Olson

E. 1411 Mission Avenue

Spokane, WA 99202

Water Purification Associates

H. Gold

238 Main Street

Cambridge, MA 02142

Western States Water Council

J. A. Barnett

Executive Director

220 South 2nd East

Suite 200

Salt Lake City, UT 84111

Westinghouse Electric Corp.

G. E. Jablonka

Power Generation Systems

Engineering

700 Braddock Avenue Room 9L51

East Pittsburgh, PA 15112 
No. of

Copies

Westinghouse Electric Corp.

K. Kesavan

Advanced Reactor Division

P.0. Box 158

Madison, PA 15663

Westinghouse Electric Corp.

G. J. Silvestri

Steam Turbines Division - G108

Lester Branch

Box 9175

Philadelphia, PA 19113

Westinghouse Electric Corp.

K. A. Oleson

Steam Turbines Division - G108

Lester Branch

Box 9175

Philadelphia, PA 19113

William M. Rice University

W. G. Characklis

Environmental Science and

Engineering

Houston, TX 77001

\section{ONSITE}

DOE Richland Operations Office

Energy Programs Division

H. E. Ransom

Westinghouse Hanford Company

Hanford Engineering Development Laboratory

J. Fletcher

Pacific Northwest Laboratory

R. T. Allemann

J. A. Bamberger

David J. Braun

J. W. Currie

D. E. Deonigi
No. of

Copies

Pacific Northwest Laboratory (contd)

R. L. Dillon

D. W. Dragnich

R. L. Drake

F. P. Fabro

D. W. Faletti

J. W. Finnigan

T. J. Foley

J. D. Goodenough

J. J. Hauth

A. J. Haverfield

C. H. Henager

A. B. Johnson

W. S. Kelly

R. S. Kemper

W. V. Loscutoff

R. P. Marshall

D. E. Olesen

M. S. 01 sen

Y. Onishi

H. L. Parry

L. T. Pedersen

G. C. Smith

J. S. Stoakes

A. M. Sutey

R. D. Tokarz

D. S. Trent

M. Vagins

R. A. Walter

R. L. Watts

R. D. Widrig

L. E. Wiles

C. E. Willingham

F. R. Zaloudek

File - B. M. Johnson (30)

Technical Information (5)

Publishing Coordination (2) 
,

. 